Portland State University

PDXScholar

7-23-1974

\title{
An Automatic Rinse Tank Controller for Industrial Applications
}

\author{
Aliasghar Emami \\ Portland State University
}

Follow this and additional works at: https://pdxscholar.library.pdx.edu/open_access_etds

Part of the Industrial Engineering Commons, and the Materials Science and Engineering Commons Let us know how access to this document benefits you.

\section{Recommended Citation}

Emami, Aliasghar, "An Automatic Rinse Tank Controller for Industrial Applications" (1974). Dissertations and Theses. Paper 2169.

https://doi.org/10.15760/etd.2167

This Thesis is brought to you for free and open access. It has been accepted for inclusion in Dissertations and Theses by an authorized administrator of PDXScholar. Please contact us if we can make this document more accessible: pdxscholar@pdx.edu. 
AN ABSTRACT OF THE THESIS OF Allasghar Emami for the Master of Science in Applied Science presented July 23, 1974.

Title: An Automatic Rinse Tank Controllex for Industrial Applications. APPROVED BY MEMBERS OF THE THESIS COMMITTEE:
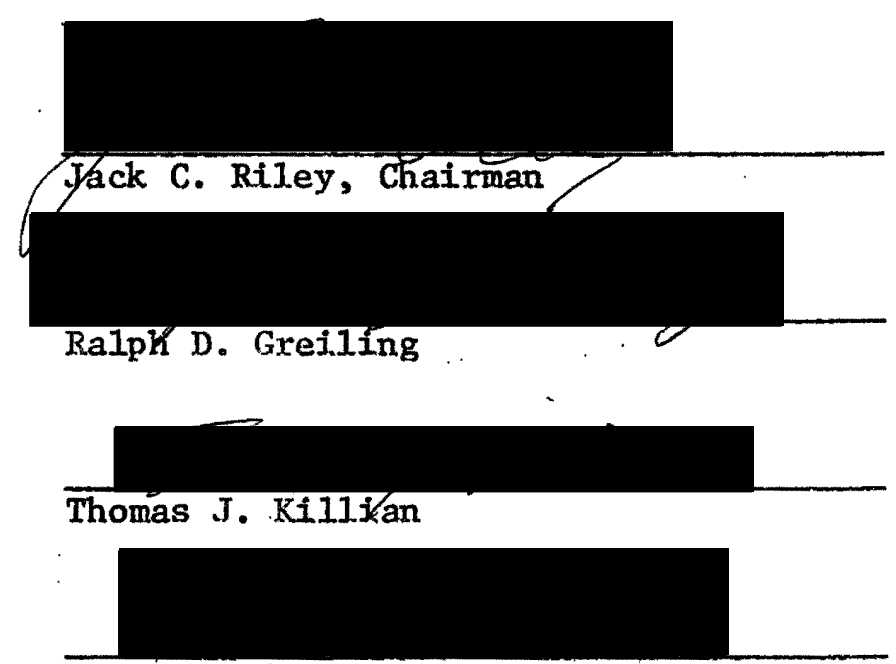

Robert W. Rempfer

This thesis describes an automatic Rinse Tank Control System used in detection and removal of contaminating agents from industrial plating rinse tanks. It automatically monitors the purity of the rinse water in sixteen separate rinse tanks, and permits fresh water to enter the tanks only when the conductivity of the rinse water in each tank exceeds a predetermined level. Its use will result in large savings in consumption of fresh water and the subsequent reduction in discharge of effluent to the treatment plants. 
AN AUTOMATIC RINSE TANK CONTROLLER

FOR INDUSTRIAL APPLICATIONS

by

ALIASGHAR EMAMI

A thesis submitted in partial fulfillment of the requirements for the degree of

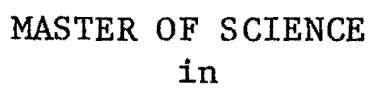

Portland State University 1974 
TO THE OFFICE OF GRADUATE STUDIES AND RESEARCH:

The members of the Committee approve the thesis of Aliasghar Emami presented July 23, 1974.
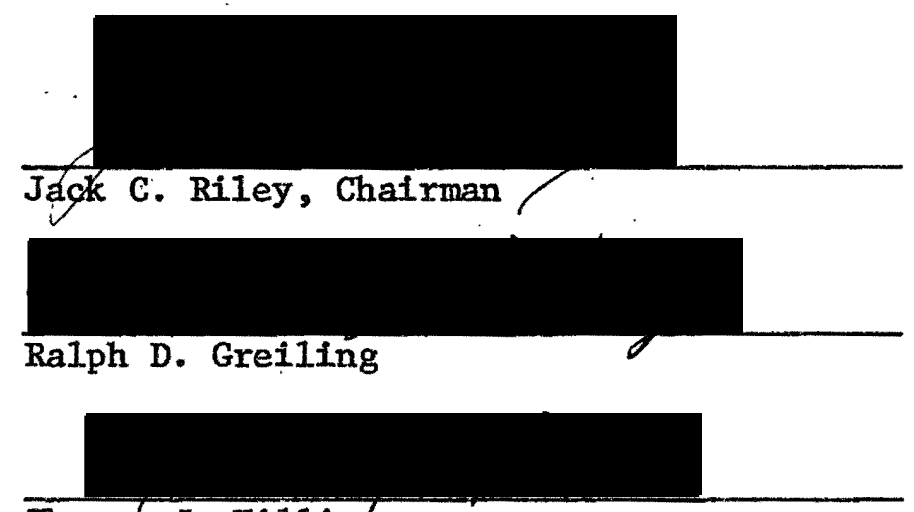

Thomas J. Ki11ian

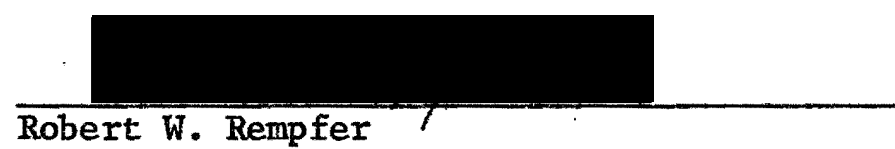

APPROVED:

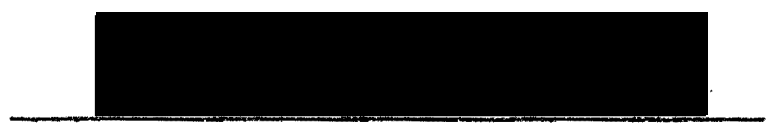

Nan-Teh Hsu, Department Head

Applied Sclence and Engineering

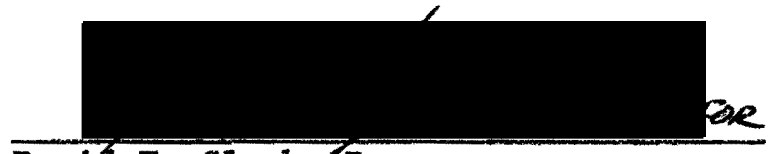

Daviá T. Clark/ Dean

Graduate Studies and Research 
IN MEMORY OF MY FATHER

MEHDI EMAMI 


\section{ACKNOWLEDGMENT}

The author is greatly indebted to Ms. Becky Van Grunsven of the Electrochemical Research and Development group at Tektronix, Inc. for her invaluable guidance during the development and subsequent evaluation of the automatic rinse tank control system.

It is also a pleasure to acknowledge the continuing technical support from Mr. James Kellogg of the Network Analyzer Research group, whose electronic wizardry made the analog to digital converter design possible. 
TABLE OF CONTENTS

PAGE

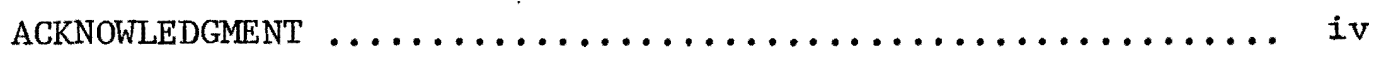

LIST OF TABLES $\ldots \ldots \ldots \ldots \ldots \ldots \ldots \ldots \ldots \ldots \ldots$ vii

LIST OF FIGURES $\ldots \ldots \ldots \ldots \ldots \ldots \ldots \ldots \ldots \ldots \ldots \ldots \ldots \ldots \ldots \ldots \ldots \ldots$

INTRODUCTION $\ldots \ldots \ldots \ldots \ldots \ldots \ldots \ldots \ldots \ldots \ldots \ldots \ldots \ldots \ldots \ldots$

BACKGROUND $\ldots \ldots \ldots \ldots \ldots \ldots \ldots \ldots \ldots \ldots \ldots \ldots \ldots \ldots \ldots \ldots \ldots \ldots \ldots \ldots$

RINSE TANK CONTROL $\operatorname{SYSTEM} \ldots \ldots \ldots \ldots \ldots \ldots \ldots \ldots \ldots \ldots \ldots \ldots$

I DESIGN CONSIDERATION $\ldots \ldots \ldots \ldots \ldots \ldots \ldots \ldots \ldots \ldots$

II BASIC SYSTEM DESCRIPTION $\ldots \ldots \ldots \ldots \ldots \ldots \ldots \ldots \ldots$

III GENERAL DESCRIPTION $\ldots \ldots \ldots \ldots \ldots \ldots \ldots \ldots \ldots \ldots$

IV DETAILED DESCRIPTION $\ldots \ldots \ldots \ldots \ldots \ldots \ldots \ldots \ldots$

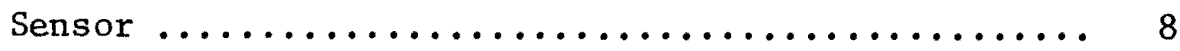

Buffered $200 \mathrm{~Hz}$ 0scillator ................. 8

Sensor Amplifier ..................... 9

Positive Peak Detector ................... 12

Analog to Digital Convertor .............. 12

Programmable Memory $\ldots \ldots \ldots \ldots \ldots \ldots \ldots \ldots \ldots \ldots$

Digital Comparator $\ldots \ldots \ldots \ldots \ldots \ldots \ldots \ldots \ldots \ldots$

Output Driver $\ldots \ldots \ldots \ldots \ldots \ldots \ldots \ldots \ldots \ldots \ldots \ldots \ldots$

Zero Crossing Detector $\ldots \ldots \ldots \ldots \ldots \ldots \ldots \ldots \ldots$

Control Logic $\ldots \ldots \ldots \ldots \ldots \ldots \ldots \ldots \ldots \ldots \ldots \ldots \ldots \ldots \ldots$

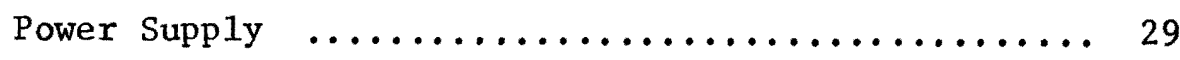

Construction $\ldots \ldots \ldots \ldots \ldots \ldots \ldots \ldots \ldots \ldots \ldots \ldots \ldots$

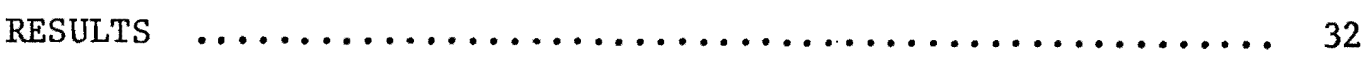

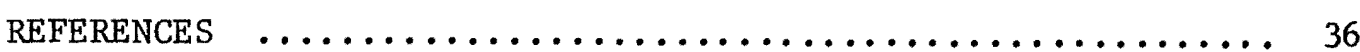

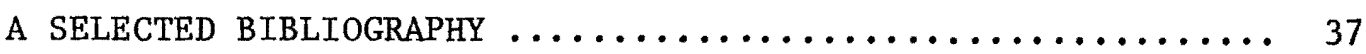


PAGE

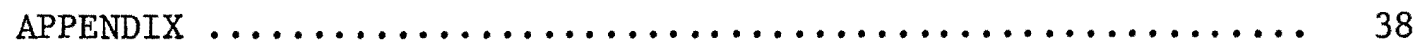

System Analog/Reference Clock Generator............ 39

Partial Control Logic Circuit Diagram ........... 40

A/D Converter Timing Diagram $\ldots \ldots \ldots \ldots \ldots \ldots \ldots \ldots, 41$

Analog to Digital Converter $\ldots \ldots \ldots \ldots \ldots \ldots \ldots \ldots, 42$ 


\section{LIST OF TABLES}

TABLE

PAGE

I Function Table for 4 Bit Comparator $\ldots \ldots \ldots \ldots \ldots \ldots . \ldots 19$

II Truth Table for $J-K$ Flip Flop $\ldots \ldots \ldots \ldots \ldots \ldots \ldots \ldots \ldots$

III

Standard Solution Concentrations

33 


\section{LIST OF FIGURES}

FIGURE

PAGE

Photograph of RTC-16 System ............ Frontispiece

1 System Block Diagram $\ldots \ldots \ldots \ldots \ldots \ldots \ldots \ldots \ldots \ldots \ldots \ldots$

2 Wien-Bridge Oscillator $\ldots \ldots \ldots \ldots \ldots \ldots \ldots \ldots \ldots \ldots$

3 Sensor Amplifier ........................ 11

4 Positive Peak Detector ...................... 13

$5 \quad$ A/D Converter Block Diagram .................... 15

6 Programmable Memory $\ldots \ldots \ldots \ldots \ldots \ldots \ldots \ldots \ldots \ldots \ldots \ldots$

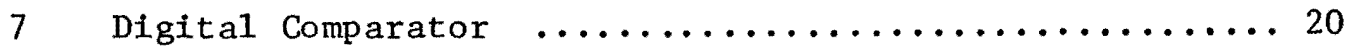

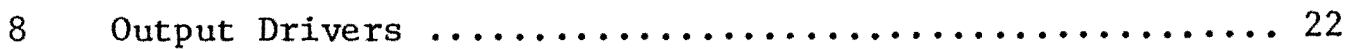

$9 \quad$ Zero Crossing Detector ............................ 24

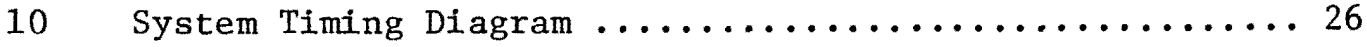

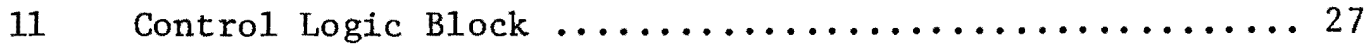

12 System Power Supply $\ldots \ldots \ldots \ldots \ldots \ldots \ldots \ldots \ldots \ldots \ldots \ldots$

13 Cyclic Variation in Tank Number $371 \ldots \ldots \ldots \ldots \ldots$ 


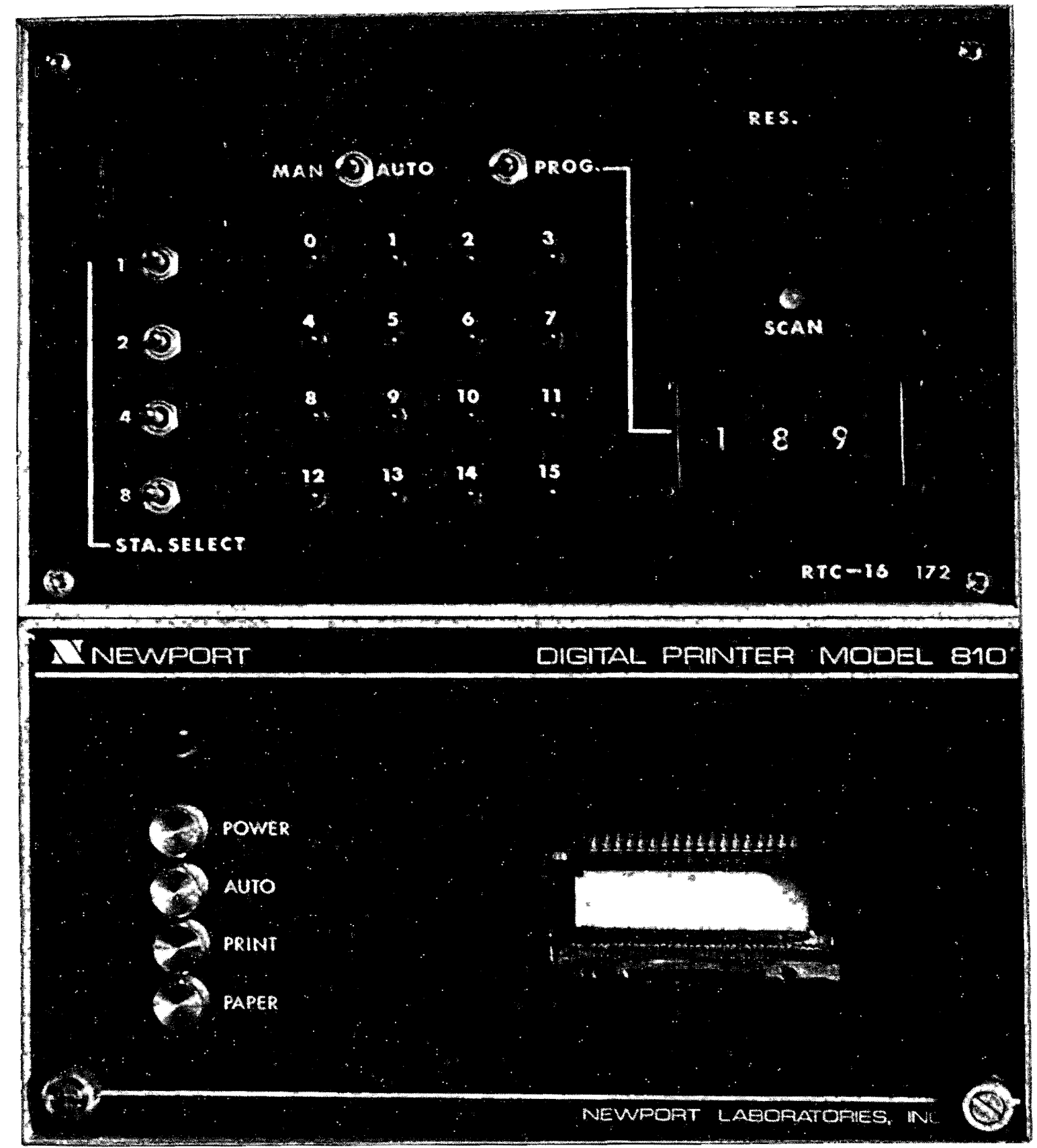




\section{INTRODUCTION}

\section{BACKGROUND}

Reduction of water consumption has become an increasingly vital consideration for the plating industry. Wastes require more extensive treatment in municipal water system and sewage charges, based on quantity, are becoming common in industrial communities. Increasing water shortage makes conservation essential.

Usual procedure in most plating rooms is to throttle cold rinse tank valves at the start of the first shift. Water will continue to run until the end of the first or second shift. These tanks are needlessly discharging clean water at a constant rate. Since an average plating facility will use 25 to 30 of these cold rinse tanks, the result is a tremendous amount of wasted water.

A large saving in water consumption can be realized if the flow of water into these rinse tanks could be restricted to an amount necessary to keep contaminating chemicals diluted to an acceptable concentration. The water flow could be automatically shut off whenever use of the tanks is interrupted.

For example, let us look at a barre1 cadmium plating operation. The cycle consists of cleaning, rinsing, acid pickling, rinsing, cyanide dipping, cadmium plating, drag out rinsing, cold rinsing, and hot rinsing. Note that there are three cold rinse tanks involved. 
Each tank is constantly flowing at a rate of about $20 \mathrm{gpm}$ (gallons per minute).

The entire cycle is complete in approximately one hour, about five or six minutes of which is spent for cold rinsing to remove all contaminants. Total water used per hour would be 3600 gallons ( 3 tanks $\times 20$ gpm $\times 60$ minutes $=3600$ gallons per hour $)$.

The same situation under controlled conditions would have the same load, the same average time for rinsing, and the same three tanks. The difference is that the water is shut off automatically when rinsing has been completed. Under this control, water consumption would be 360 gallons ( 3 tanks $\times 20$ gpm $\times 6$ minutes $=360$ gallons $)$ or $10 \%$ of that used without control.

Two important benefits would result from an automatic control of the rinse tank flow. One is the enormous water savings. A plating facility uses a large number of rinse tanks and the example given shows that hundreds of thousands of gallons per day could be saved.

The second benefit is the reduction of effluent to the treatment plant. Since most treatment plants have restricted outflows from their plants into municipal water systems, this reduction could make present or future expansions possible. It could also remove the threat of penalty by insuring a discharge below the allotted amount.

Tektronix, Inc. has had a considerable problem in this area. As early as 1969 , the rate of outflow had nearly equalled the allotted amount of 400,000 gallons per day or approximately 12 million gallons per month. The average outflow at that time was about 11 milition gallons per month. 
With completion of new construction, an additional 2.5 mil1ton gallons per month would have to be treated and ultimately released into Beaver Creek. This would result in violation of the permit and subsequent payment of heavy fines which would be levied upon the company monthly. The author, an employee of Tektronix, was delegated the task of a feasibility study and subsequent design of an automatic rinse tank control system to alleviate this problem.

Initial experiments with eighteen manually controlled rinse tanks revealed that controlling even one-half of the hot and cold rinse tanks would lower water usage and subsequent discharge by 4.5 million gallons per month. It was decided that a reduction of this magnitude would have the following results:

1) An increase of the treatment capacity with a resultant delay in the expansion of the present treatment facility; and

2) An increase in the retention time of effluent in the lagoons, thereby resulting in better and more complete treatment of solids and precipitates.

These findings were the basis for initiating a project to design a Rinse Tank Contro1 System (RTC-). 


\section{DESIGN CONSIDERATION}

An automatic Rinse Tank Control System would automatically monitor the purity of the rinse water in a selected number of rinse tanks and permit fresh water to enter the tanks only when the contamination level in each tank exceeds a predetermined level. It should automatically turn off the flow of fresh water when the contamination level drops below its pre-set value. Such obvious variables as the quality of the water supply, the frequency of tank activity, and the work load must be automatically compensated for, in order to maintain the appearance and quality of the finished product. It must be capable of operation under the adverse conditions which often exist in a plating operation. These conditions, as well as many others, shaped the guide lines which formed the basis for the design and fabrication of the RTC system.

\section{BASIC SYSTEM DESCRIPTION}

The RTC System basically consists of (a) a number of sensors which sense the electrical conductivity of the rinse tank contents, (b) a control unit containing the scanning, measurement and relay control circuits and (c) a number of normally closed, solenoid operated water valves.

Two versions of this instrument were designed and fabricated. The first version (RTC-16), basically a 16-channel laboratory type instru- 
ment, was designed to operate in a controlled environment. It was used to determine the allowable amount of contaminants' in different rinse tanks and to investigate cyclic changes in these tanks during peak and slack periods.

The second version (RTC-10), a 10-channe1. instrument, was a simpler device, ruggedized to withst and the long, trouble-free service demanded by the plating department.

The 16-channel RTC system, due to the complex nature of its electronics, presented much challenge, both in design and fabrication. It was therefore selected as the subject of this paper.

\section{GENERAL DESCRIPTION}

A block diagram of the RTC-16 system is shown in Fig. 1 and is provided for necessary reference. Following is a brief description of the basic sections in the system:

1) Sixteen sensors whose output is proportional to the amount of contaminants in the rinse tanks in which they are submerged.

2) A buffered, $200 \mathrm{~Hz}$ sine-wave oscillator which provides the AC signal to the sensors in order that the variation in their output can be detected.

3) A sensor amplifier which is basically an operational amplifier with a selected sensor in its feed back loop. It converts variations in the output of the sensor to a proportional AC voltage.

4) A positive peak detector which retains the peak value of the $\mathrm{AC}$ voltage from sensor-amplifier.

5) An analog to digital converter which converts the peak 


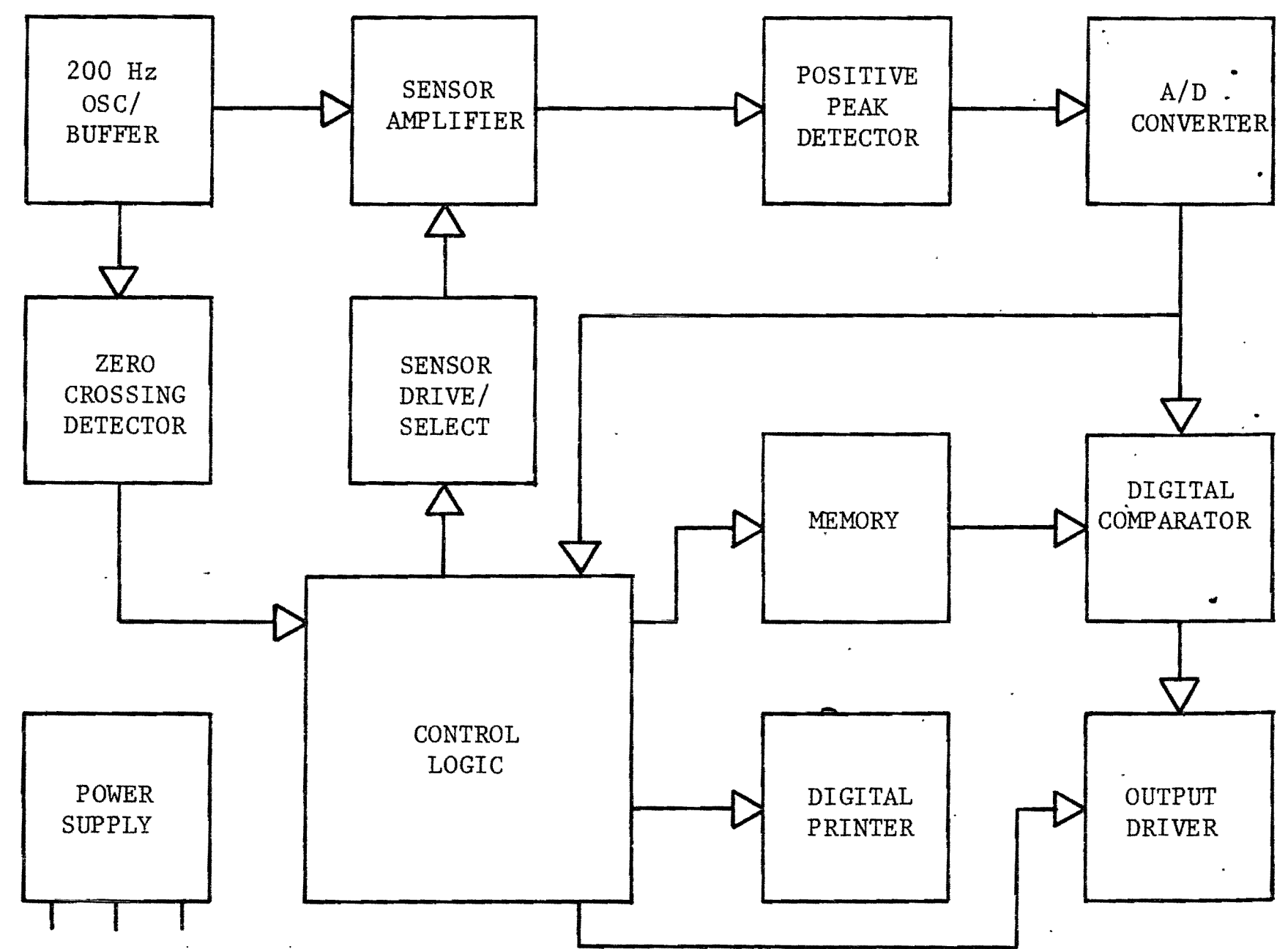

TO ALL SECTIONS

Figure 1. System Block Diagram 
voltage from the positive peak detector to a $2 \frac{1}{2}$ digit Binary Coded Decimal number.

6) A $16 \times 10$ bit programmable memory, used to generate a reference number which is compared against the A/D converter output.

7) A digital comparator which compares the output of the $A / D$ converter. to that of the programmable memory.

8) An output driver which will either activate a selected output or bypass it, based on its input from the digital comparator.

9) A zero crossing detector which generates an appropriate output every time the $200 \mathrm{~Hz}$ sine wave crosses zero. This output is used as the system clock in the control logic circuitry.

10) The control logic section uses the zero crossing output as reference for generating appropriately timed signals which are used throughout the system.

11) A regulated \pm 15 and +5 volt power supply which powers the system.

To illustrate how the system operates, one cycle of operation will be explained in detail.

One of sixteen sensors is selected and AC voltage applied. This voltage is sampled by the sensor amplifier and the maximum positive peak voltage is detected by the positive peak detector. This maximum voltage is then converted to an equivalent $2 \frac{1}{2}$ digit binary coded decimal. This number is then compared to a programmed value from the programmable memory. If it is less than or equal to that value, the corresponding output, for that cell is bypassed since an equal or smaller number indicates that the contamination level in the tank is at or below a safe value for that rinse tank. 
If it is larger, the corresponding output is activated to allow fresh water to enter the rinse tank. The cycle is then repeated with the next sensor. Completion of one cycle occurs in approximately forty milliseconds or 25 complete operations every second.

\section{DETAILED DESCRIPTION}

\section{Sensor}

The sensor consists of two graphite rings spaced a fixed distance apart and encased in a sturdy epoxy housing. It is basically a con-

ductivity cell (1) whose specific conductance $\left(\mathrm{ohm}^{-1} \mathrm{~cm}^{-1}\right.$ ) variation is proportional to the ionic concentration of an electrolyte solution. Electrolyte solutions in general follow Ohm's Law $(E=I R)$. Therefore, when the sensor is immersed in such a solution and a constant current is forced through it, a voltage equal to the current divided by the conductance of the solution in between the electrodes will develop across the sensor.

$$
E_{S}=\frac{I_{S}}{G_{S}} \text { where } G_{S}=\frac{I}{R_{S}}
$$

Alternating current must be applied, since direct current will cause polarization at the electrotes of the sensor.

Conductance of the sensor varied from 50 to 5000 micromho's, which was more than adequate for this application.

\section{Buffered $200 \mathrm{~Hz}$ Oscillator}

Operational amplifier A2 and its associated circuitry form a wien-bridge oscillator which is used to power the sensing probe. As 
shown in Fig. 2, the actual wien-bridge is formed by $R_{1}, C_{1}, R_{2}$, and $\mathrm{C}_{2}$. If $\mathrm{R}_{1}=\mathrm{R}_{2}=7.96 \mathrm{~K}$ ohm and $\mathrm{C}_{1}=\mathrm{C}_{2}=0.1$ microfarad, then

$$
\begin{aligned}
& f_{0}=\frac{1}{2 \pi R_{1} C_{1}} \\
& f_{0}=200 \mathrm{~Hz}
\end{aligned}
$$

Diodes $\mathrm{D}_{1}$ and $\mathrm{D}_{2}$ are used for amplitude stability by providing negative feedback. Potentiometer $R_{3}$ controls stability as well as amplitude of the oscillations.

This circuit has high output impedance, and any loading at $e_{0}$ will in turn change the amplitude. Since the driven load in this case varies to a great degree, operational amplifier $V_{2}$ is used as a noninverting buffer to isolate the load from the oscillator.

\section{Sensor Amplifier}

It was stated earlier that an alternating current of constant magnitude must be applied to the sensor and the resulting voltage measured in order that the electrolyte solution conductivity may be calculated. Use of an operational amplifier makes this a rather easy task. The circuit of Fig. 3 is a voltage-to-current converter which operates in the inverting mode. The input current is given by:

$$
i_{i n}=\frac{e_{i n}}{R_{7}}
$$

Since $R_{7}$ is terminated at the virtual ground of the summing junction, this same current flows through the feedback load impedance $z_{1}$ (one of sixteen sensors). The current $i_{i n}$ is independent of the 


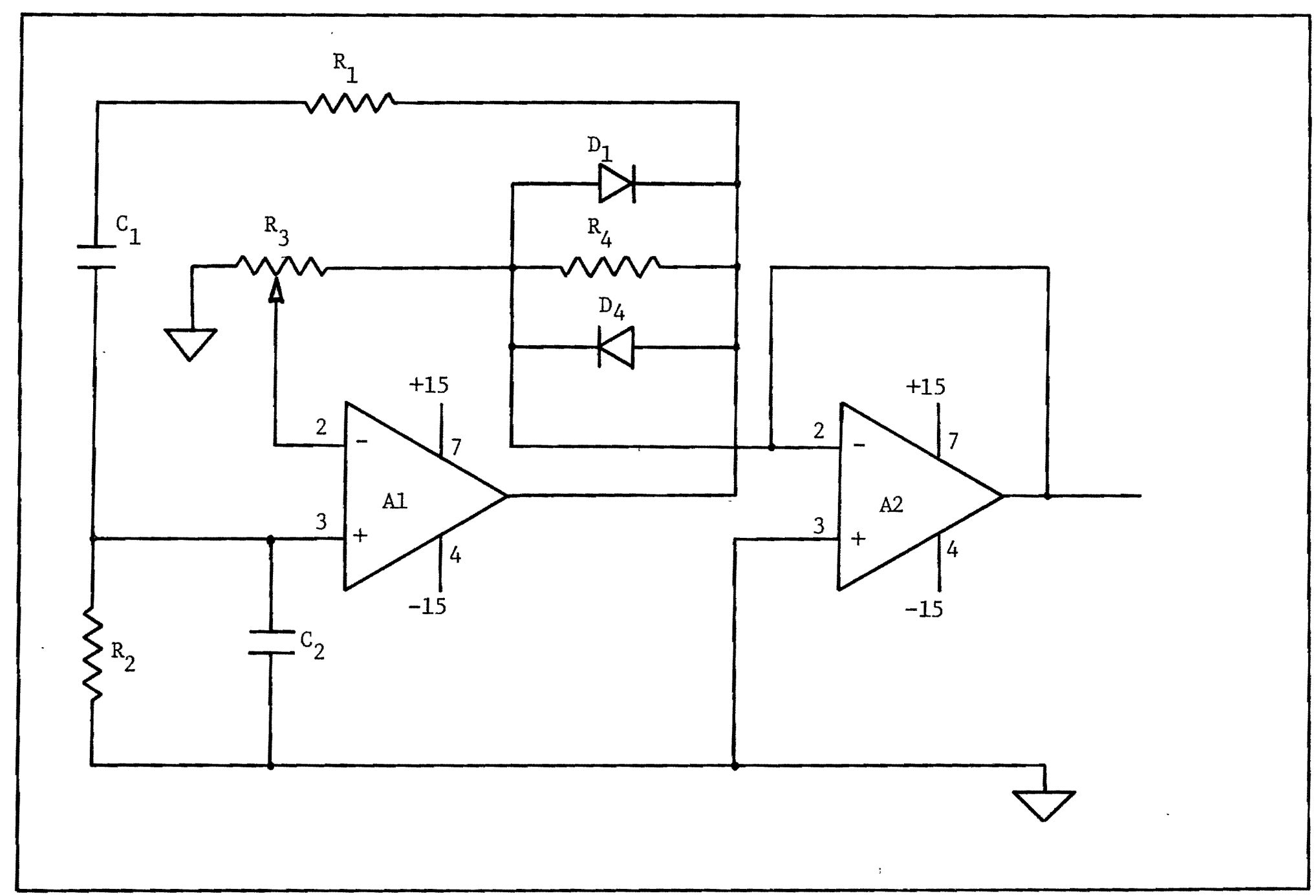

Figure 2. Wien-Bridge Oscillator 


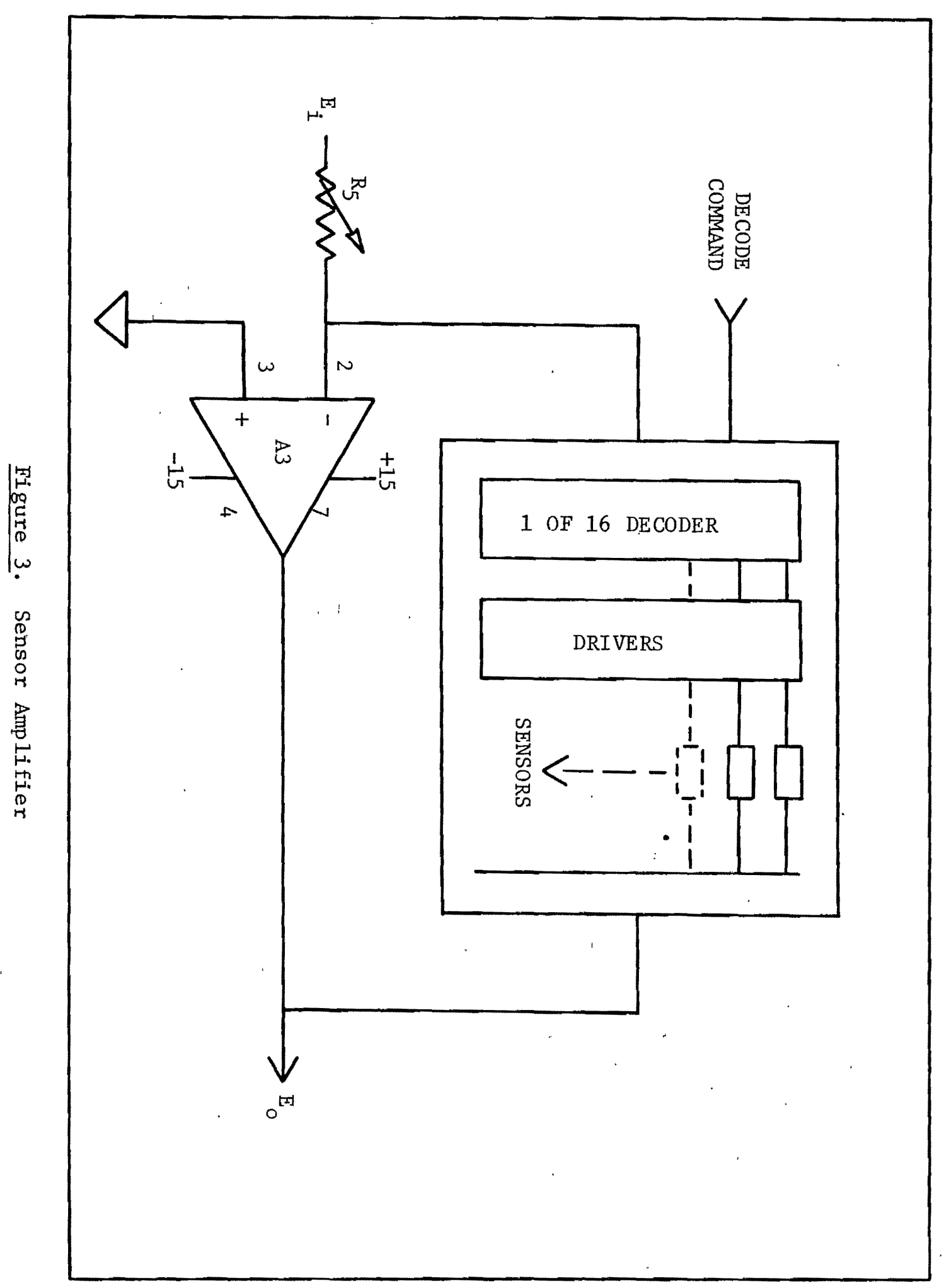


value of $Z_{L}$. The output voltage is then

$$
e_{0}=-e_{\text {in }}\left(Z_{L} / R_{7}\right)
$$

This voltage is proportional to the conductance (actually resistance) of the sensor which is selectively placed in the feedback loop through digitally controlled solid state switches. Resistor $R_{7}$ is adjusted for 7.89 volts at the output terminal of the positive peak detector. This gives a full scale reading of 20.0 at the output of the analog to digital converter.

\section{Positive Peak Detector}

A peak detector is a special form of sample and hold circuit. Basically, the input signal is tracked until it reaches its maximum value and then the peak detector automatically holds this peak value: The peak detector which was used in this instrument is shown in Fig. 4. Operational amplifiers $\mathrm{A} 4$ and $\mathrm{A} 5$ and their associated circuitry form the peak detector. Capacitor $\mathrm{C}_{6}$ is the memory element for the peak detector. It charges to the peak voltage and holds that value until reset. Diode $\mathrm{D}_{4}$ allows only the positive portion of the input to reach $C_{6}$. Diode $D_{3}$ supplies negative feedback for $A 4$ when $e_{i}$ is less than $e_{0}$. Solid state switch $S_{1}$ is controlled digitally. It is activated for five milliseconds prior to the end of each cycle to discharge $\mathrm{C}_{6}$ before the next cycle starts.

\section{Analog to Digital Converter}

A modular analog to digital converter was designed to convert the output voltage from the positive peak detector to an equivalent 


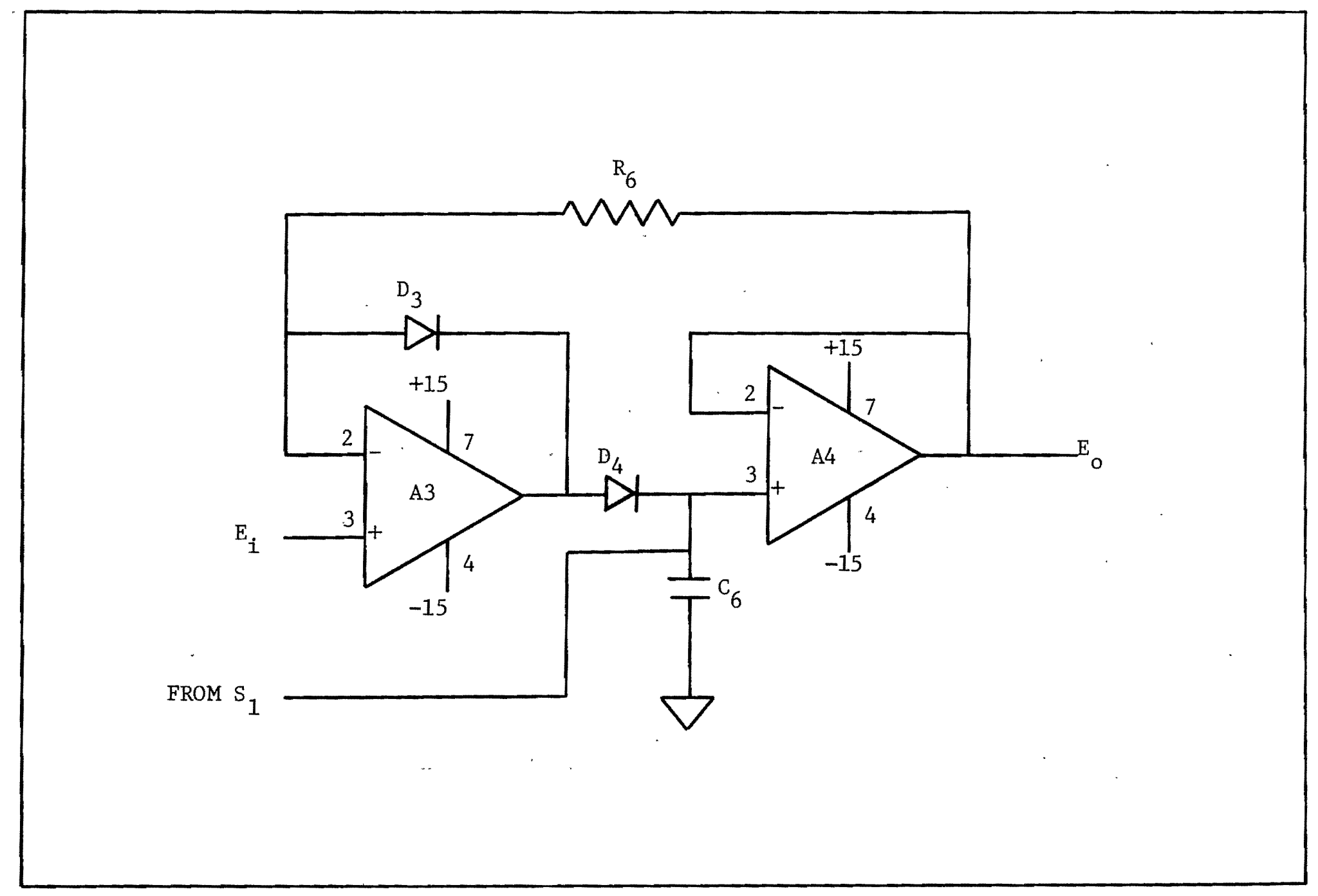

Figure 4. Positive Peak Detector 
$2 \frac{1}{2}$ digit binary coded decimal number. The block diagram for the A/D converter is shown in Fig. 5. For a complete schematic as we11 as the timing diagram, the reader is referred to Appendix $I$.

The A/D converter is essentially a dual slope integrator with a conversion time of 200 microseconds. Its operation is briefly as follows.

On negative transition of a one microsecond Strobe pulse, FET Switch No. 1 of U15 (Quad Field Effect Transistor Switch) is activated through its control logic (U8 $\left.8_{b}, U 7_{b}, U 5_{a}\right)$, thus allowing A7 to integrate the analog input signal. This transition also activates decode counters U9, U10, and U11, which then will count up towards full scale at a $2.56 \mathrm{M} \mathrm{Hz}$ rate. When the full scale count is reached, the counters will reset to zero. The full scale pulse, through the appropriate control logic, will also turn FET No. 1 off and FET No. 2 on. This FET switch applies a reference voltage with a polarity opposite to that of the analog input signal to the integrator. This voltage will cause the integrator to integrate down towards zero volts (by removing the stored charges from the integrating capacitor). At the same time, the counter has started to count up since the zero reset pulse has been removed. When the integrator reaches zero volts, it activates comparator (A8), which has been designed to change its state abruptly when it senses zero volts at its input. The output of the comparator, through its control logic circuitry will accomplish the following:

a) Cause the counters to stop at a count which is proportional to the analog input;

b) Transfer this count to a series of latches (U12, U13, U14) 


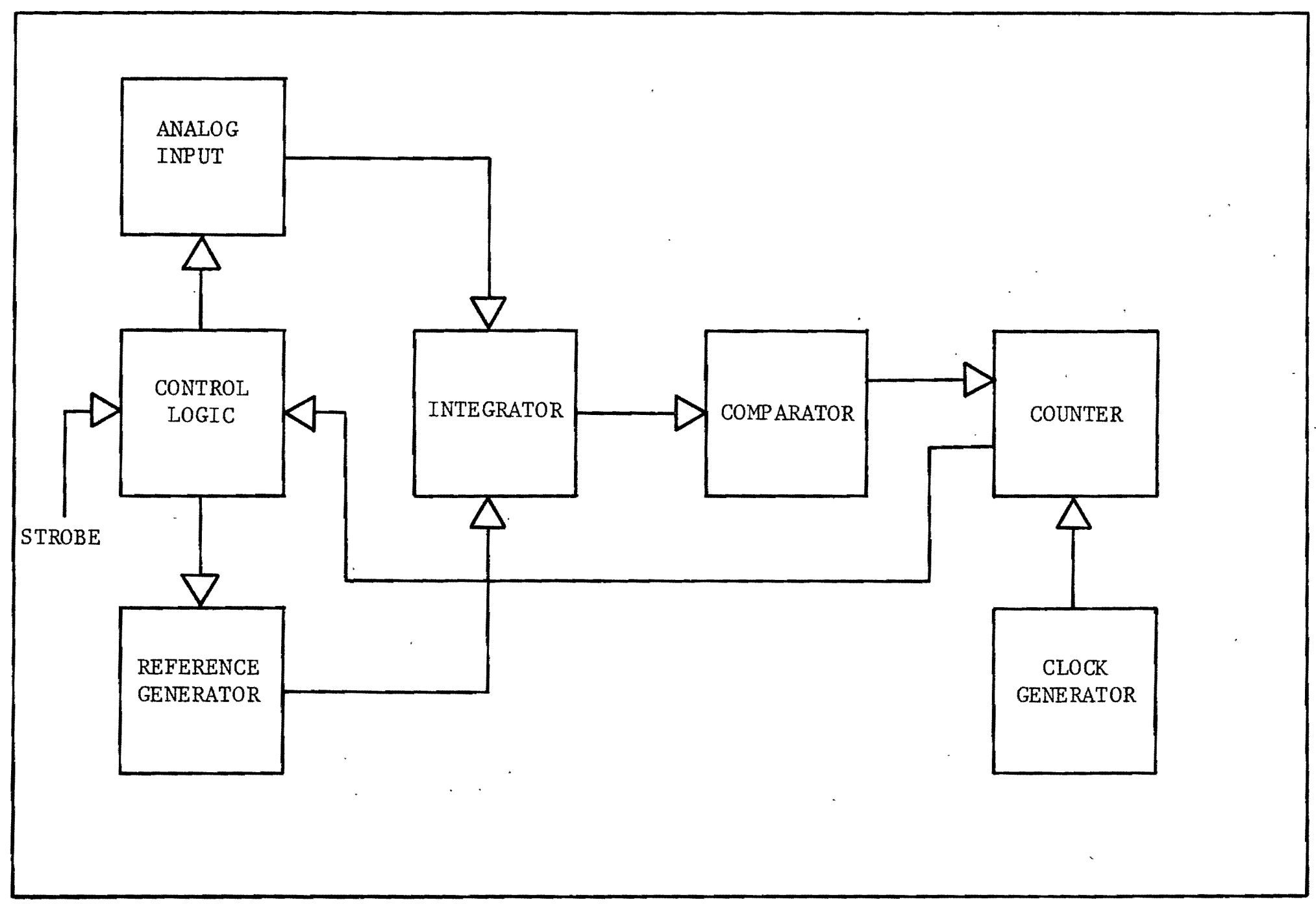

Figure 5. A/D Converter Block Diagram 
to be used at a later time; and

(c) Activate FET Switch No. 3 to short out the integrating capacitor momentarily, in order to remove all residual charges which can contribute to an error during the next cycle.

When this operation is complete, the output of the $A / D$ converter will be a $2 \frac{1}{2}$ digit Binary Coded Decimal number $(00.0$ to 20.0$)$ which is directly proportional to the output of the positive peak detector.

\section{Programmable Memory}

A $16 \times 10$ bit programmable memory was used to (a) store $2 \frac{1}{2}$ digits of information from the A/D converter automatically; and (b) store 10 $\mathrm{BCD}$ bits of information from an external source (front panel thumbwheel switches).

The circuit diagram for the programmable memory is shown in Fig. 6. The actual memory was designed using Texas instrument type SN7489, 64 bit Read/Write memory. It contains 64 flip flop memory cells, organized in a matrix to provide 16 words of four bits each. The buffered memory inputs consist of four data inputs, four address lines, a write enable, and a memory enable. The four sense outputs are of open-collector type and must be used in conjunction with pullup resistors.

Since a $16 \times 10$ bit memory array was needed, three integrated circuits (U16, U17, U18) were cascade to obtain the $16 \times 10$ bit capability. Note that the last two memory columns in U18 were not used. U19, U20, and U21 determine the program source for the array. 


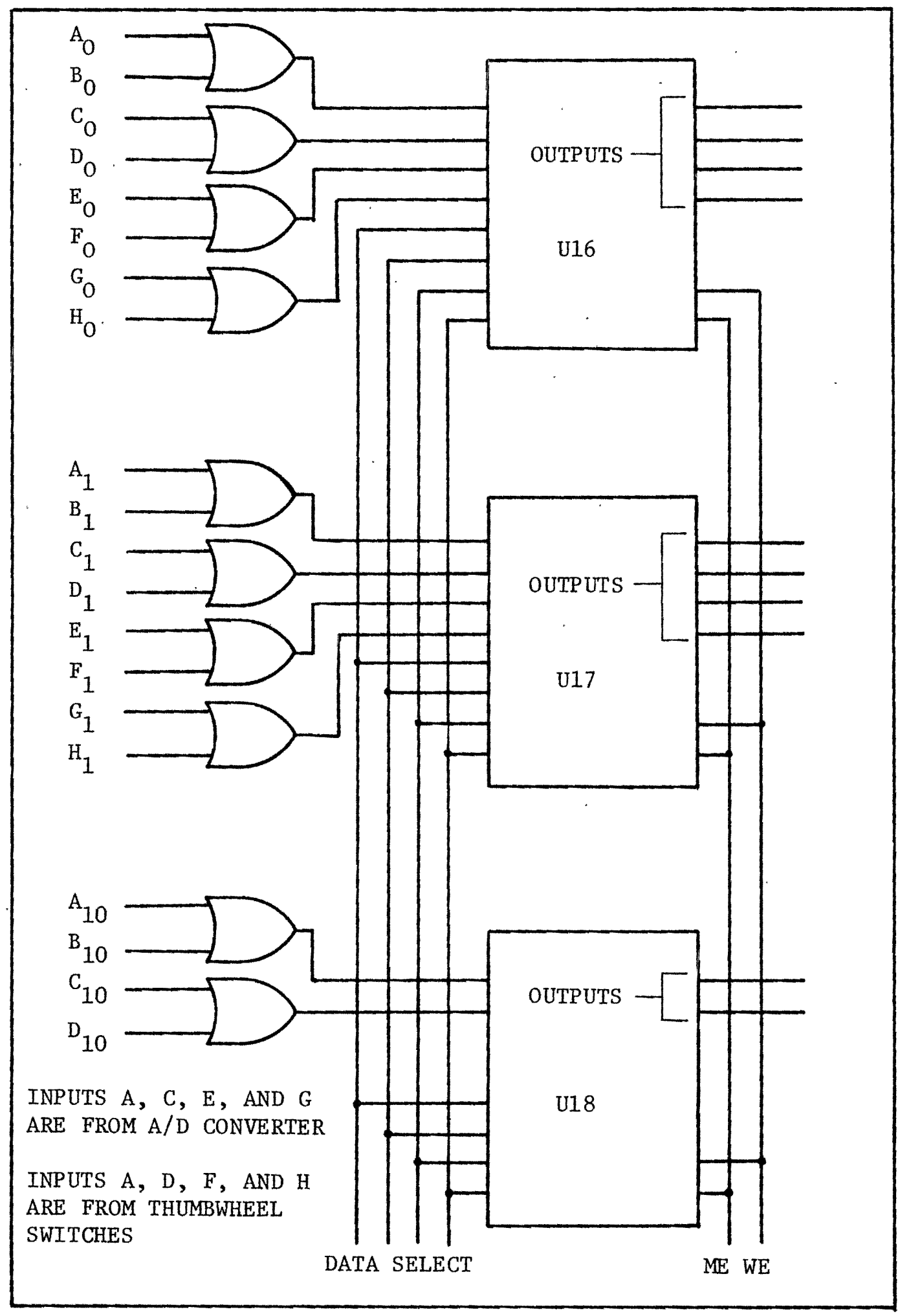

Figure 6. Programmable Memory 
Digital Comparator

A 10 bit magnitude comparator was designed to perform $B C D$ (8-4-2-1) comparison of the A/D converter and the programmable memory outputs. Three fully coded decisions about these two 10 bit BCD words $(A, B)$ are made and are externally available at three outputs $(A>B, A=B, A<B)$. Table $I$ is a function table for a 4 bit magnitude comparator using $4 \mathrm{BCD}$ words as inputs. A circuit diagram for the 10 bit magnitude comparator is shown in Fig. 7.

$(A<B)$ output is active when the contents of $A / D$ converter is less than that of the programmable memory, indicating that the ionic contamination in the rinse tank is greater than a programmed level. This output is buffered and used to activate a selected output in the output driver. $(A>B, A=B)$ outputs are used as inputs to an $O R$ gate whose output activates a green LED (Light Emitting Diode) 1ocated on the front panel to indicate a safe condition for the appropriate rinse tank. 
TABLE I

FUNCTION TABLE FOR 4 BIT COMPARATOR

\begin{tabular}{|c|c|c|c|c|c|c|}
\hline \multicolumn{4}{|c|}{ Comparing Inputs } & \multicolumn{3}{|c|}{ Outputs } \\
\hline$A_{3}, B_{3}$ & $A_{2}, B_{2}$ & $\mathrm{~A}_{1}, \mathrm{~B}_{1}$ & $A_{0}, B_{0}$ & $A>B$ & $A=B$ & $A<B$ \\
\hline $\mathrm{A}_{3}>\mathrm{B}_{3}$ & $\mathrm{x}$ & $\mathrm{x}$ & $\mathrm{x}$ & $\mathrm{H}$ & L & L \\
\hline $\mathrm{A}_{3}<\mathrm{B}_{3}$ & $\mathrm{x}$ & $\mathrm{x}$ & $\mathrm{x}$ & L & L & $\mathrm{H}$ \\
\hline $\mathrm{A}_{3}=\mathrm{B}_{3}$ & $\mathrm{~A}_{2}>\mathrm{B}_{2}$ & $\mathrm{x}$ & $\mathrm{x}$ & $\mathrm{H}$ & L & L \\
\hline $\mathrm{A}_{3}=\mathrm{B}_{3}$ & $\mathrm{~A}_{2}<\mathrm{B}_{2}$ & $\mathrm{x}$ & $\mathrm{x}$ & L & L & $\mathrm{H}$ \\
\hline$A_{3}=B_{3}$ & $\mathrm{~A}_{2}=\mathrm{B}_{2}$ & $\mathrm{~A}_{1}>\mathrm{B}_{1}$ & $\mathrm{x}$ & $\mathrm{H}$ & $\mathrm{L}$ & $\mathrm{L}$ \\
\hline$A_{3}=B_{3}$ & $\mathrm{~A}_{2}=\mathrm{B}_{2}$ & $\mathrm{~A}_{1}<\mathrm{B}_{1}$ & $\mathrm{x}$ & L & L & $\mathrm{H}$ \\
\hline$A_{3}=B_{3}$ & $A_{2}=B_{2}$ & $\mathrm{~A}_{1}=\mathrm{B}_{1}$ & $A_{0}>B_{0}$ & $\mathrm{H}$ & $\mathrm{L}$ & $\mathrm{L}$ \\
\hline$A_{3}=B_{3}$ & $\mathrm{~A}_{2}=\mathrm{B}_{2}$ & $A_{1}=B_{1}$ & $\mathrm{~A}_{0}<\mathrm{B}_{0}$ & $\mathrm{~L}$ & L & $\mathrm{H}$ \\
\hline $\mathrm{A}_{3}=\mathrm{B}_{3}$ & $A_{2}=B_{2}$ & $A_{1}=B_{1}$ & $A_{0}=B_{0}$ & L & $\mathrm{H}$ & $\mathrm{L}$ \\
\hline
\end{tabular}

$\mathrm{H}=$ High Leve $1, \mathrm{~L}=$ Low Leve1, $\mathrm{x}=$ Irrelevant 


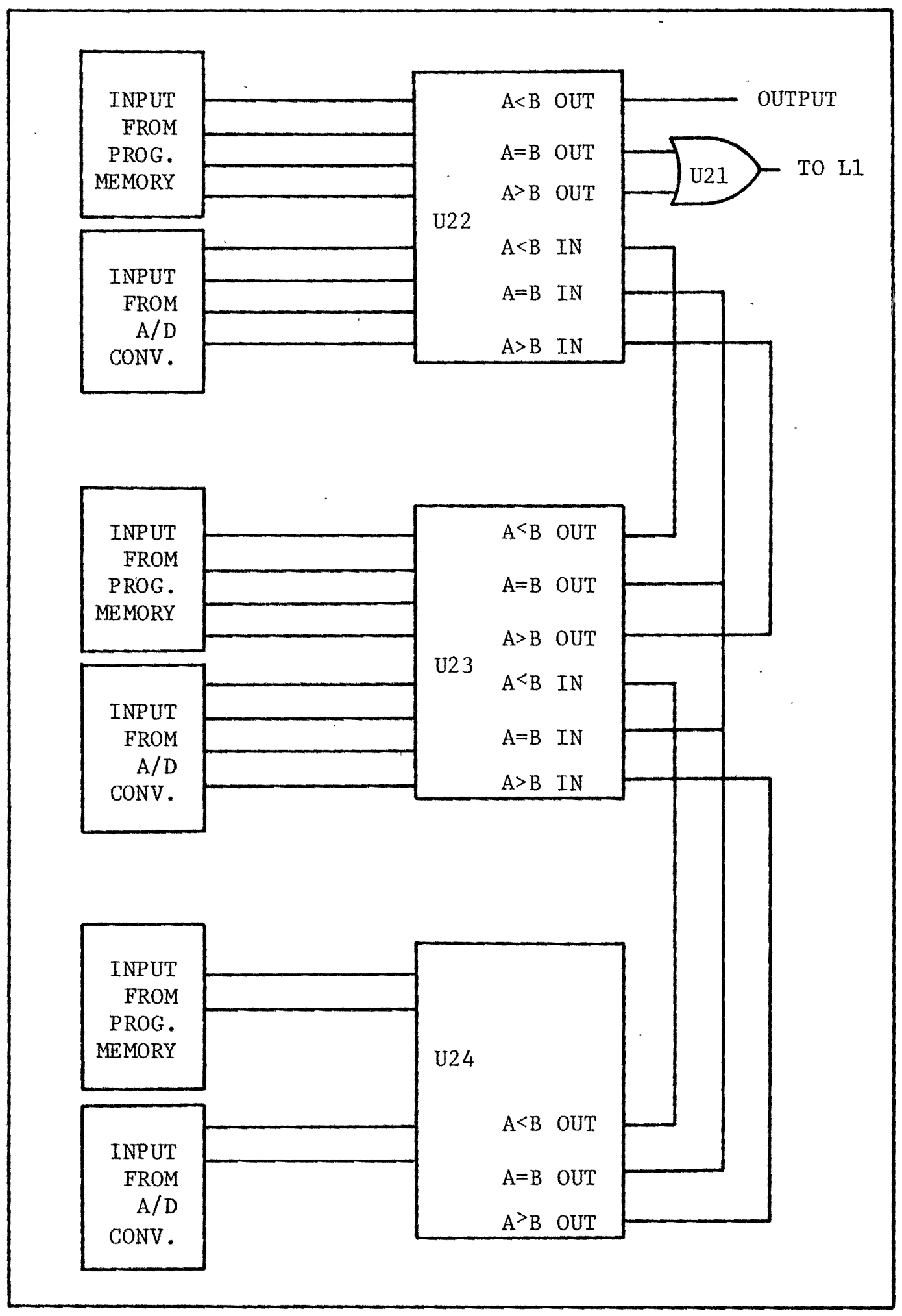

Figure 7. Digital Comparator 
Output Driver

U25 through U33 and their associated circuitry form the output drivers. A cricuit diagram for this circuit is shown in Fig. 8 . These integrated circuits are dual $\mathrm{J}-\mathrm{K}$ flip flops. A $\mathrm{J}-\mathrm{K}$ flip flop has two data inputs, $J$ and $K$, two complementary outputs $Q$ and $\bar{Q}$ and a single clock input. The truth table for a J-K flip flop is shown in Table II.

TABLE II

TRUTH TABLE FOR J-K FLIP FLOP

\begin{tabular}{|c|c|c|}
\hline \multicolumn{2}{|c|}{$T_{n}$} & $T_{n+1}$ \\
\hline$J$ & $K$ & $Q$ \\
\hline 0 & 0 & $Q_{n}$ \\
\hline 0 & 1 & 0 \\
\hline 1 & 0 & 1 \\
\hline 1 & 1 & $\bar{Q}_{n}$ \\
\hline
\end{tabular}

It is seen from the $J-K$ flip flop truth table that output $Q$ would be 0 (low) if $\mathrm{J}=0$ and $\mathrm{K}=1$ after the clock pulse transition is complete and 1 (high) if $\mathrm{J}=1$ and $\mathrm{K}=0$. These two conditions are used to control the output relays (solid state switches).

Output $(A<B)$ from the digital comparator is routed directly to the $J$ input of all flip flops and through an inverter to the $K$ input. The clock input for each flip flop originates from the control logic circuit. Whether a selected flip flop has a high or low output depends on the output condition of the digital comparator. It was stated 


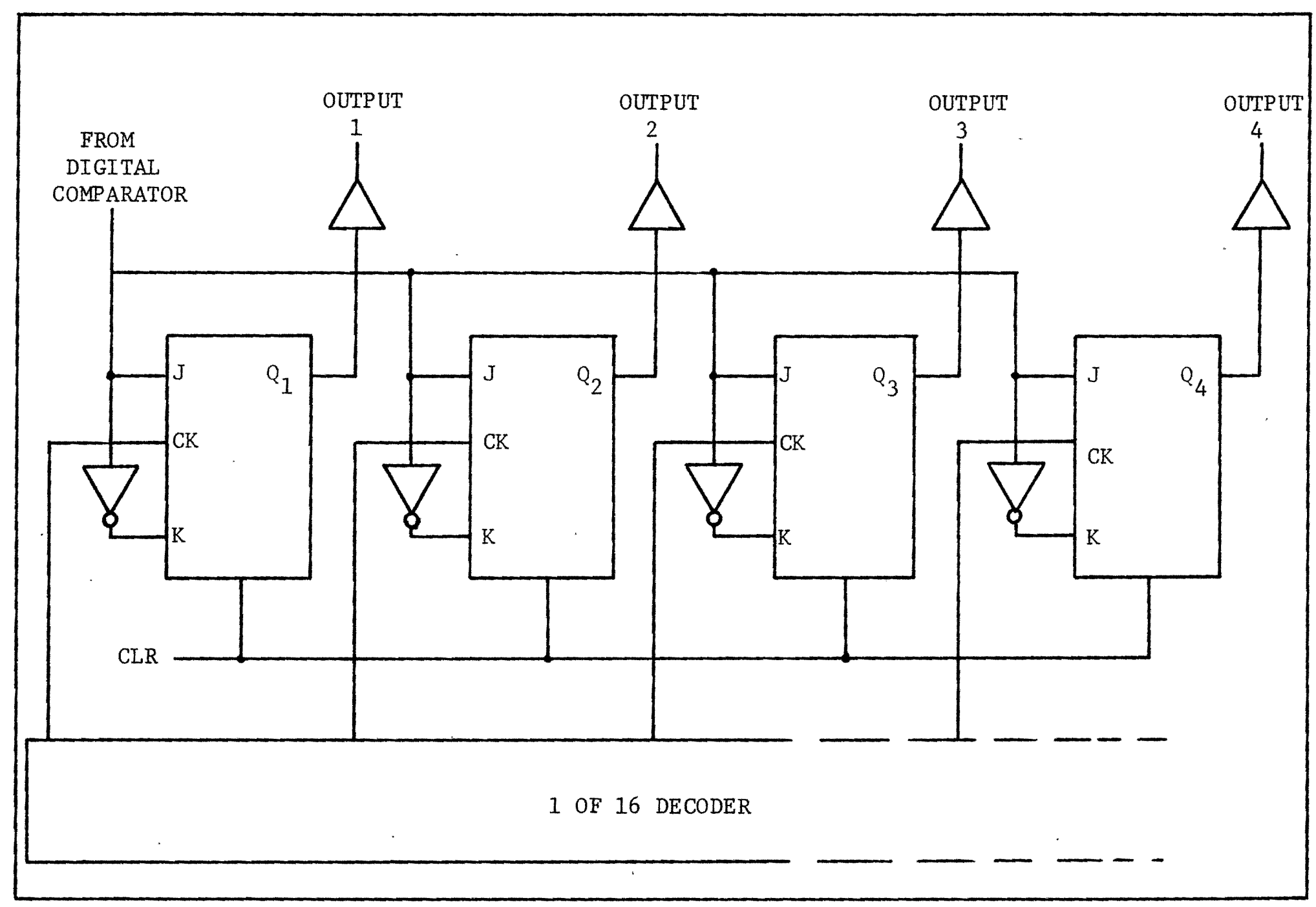

Figure 8. Output Drivers 
earlier that when the ionic contamination in a rinse tank exceeds a preset level, the $(A<B)$ output of the digital comparator assumes a high state. This causes the $J$ input of all output flip flops to assume a Logic 1. This Logic 1 is transferred to the output of only one out of sixteen digitally selected flip flops. The high state of the buffered output of this flip flop will then activate a solid state switch to throttle fresh water into the corresponding rinse tank.

\section{Zero Crossing Detector}

In order to establish a system reference which could be used by the control logic circuitry for correct timing of events in the system, a zero crossing detector using an operational amplifier was designed. It is basically a limit comparator which changes state whenever the sine wave input crosses zero volts. A circuit diagram for the zero crossing detector is shown in Fig. 9. A 3.3 volt zener, appropriately biased, was used to make detector output compatible with TTL circuitry. Output from the zero crossing detector is a square wave form with the same period as the $200 \mathrm{~Hz}$ sine wave ( 5 milliseconds).

\section{Control Logic}

Square-wave signal from the zero crossing detector has a risetime of nearly 10 microseconds. If it is used as a timing reference without any modification, one or more of the following problems may arise:

a) Rise-time sensitive devices may not operate properly.

b) Instability may result.

c) Propagation delays become very difficult to predict. For these reasons, a device to "square up" the waveform was needed. The 


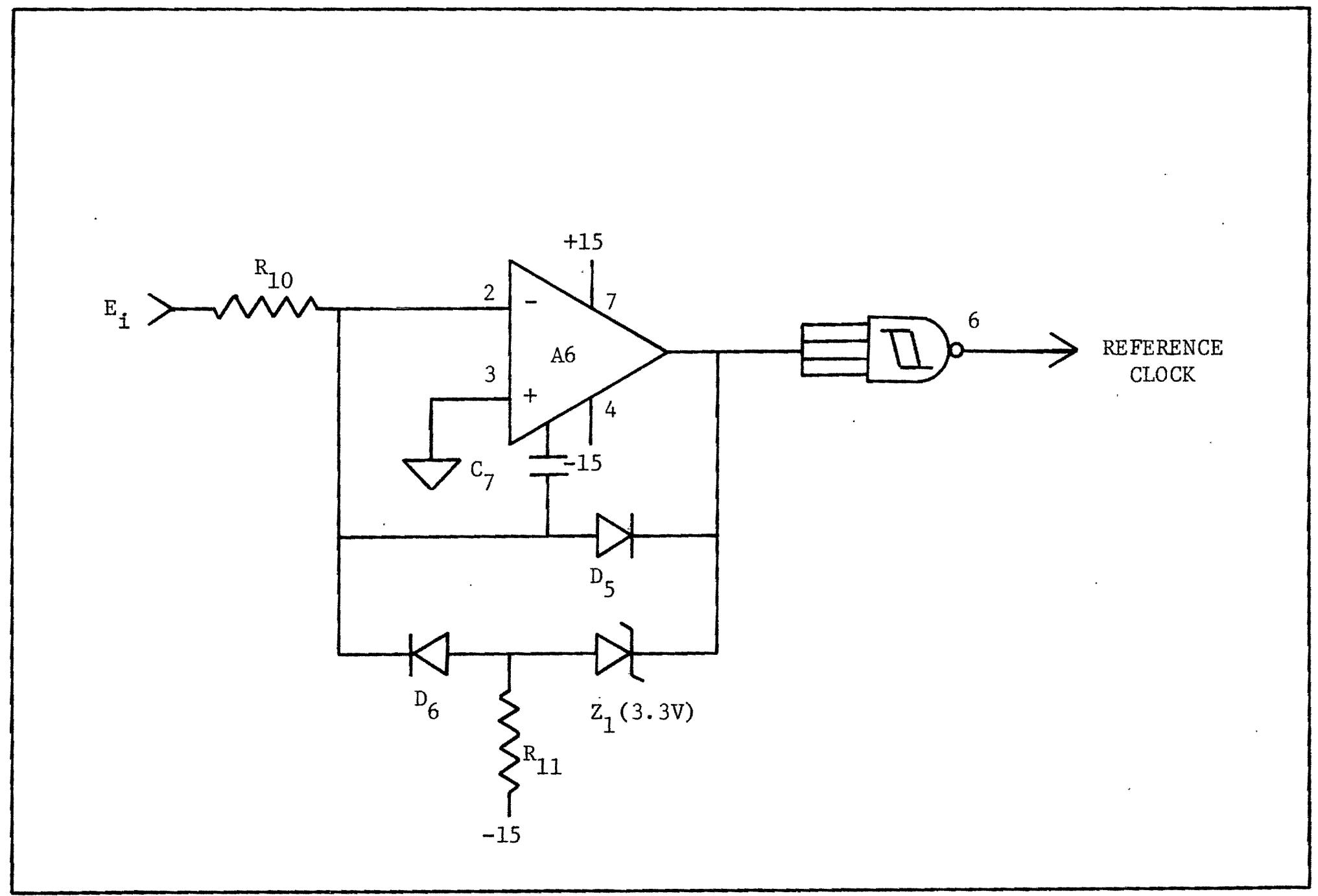

Figure 9. Zero Crossing Detector 
problem was solved using a Texas instrument type SN7413 schmitt-trigger. This device provided the pulse shaping by introducing positive feedback into a circuit to obtain high gain and hysteresis.

The system timing diagram in Fig. 10 and Control Logic Block diagram in Fig. 11 provide visual information, necessary for a full comprehension of the mechanics of the control logic section. A complete circuit diagram is included in Appendix I.

The output from the schmitt-trigger is divided by 2 , three consecutive times to yield waveforms $A, B$, and $C$.

Waveform $\mathrm{C}$ which has a period of 40 milliseconds is the input to a 1 of 16 decoder. The outputs from this decoder drive the solid state switches which place the sensors across the feedback loop of the sensor-amplifier one at a time. These switches are active during the positive transition of waveform $\mathrm{C}$ (for 20 milliseconds). This allows the positive peak detector to sample four cycles of the selected sensor voltage, thus allowing the peak detector to average out any inaccuracies which could have resulted if a single sample was taken.

Waveforms $A, B$, and $C$ are used to generate waveform $E$.

$$
E=(A \cdot \bar{B} \cdot \bar{C})
$$

where, denotes "AND" function.

Waveform $\mathrm{E}$ is applied to a 1 of 16 decoder whose function is to enable the output driver flip flops one at a time. Since this decoder is synchronized with the sensor-selector decoder, the correct sensor and output driver is selected each time.

The binary input for both decoders is provided by a programmable 


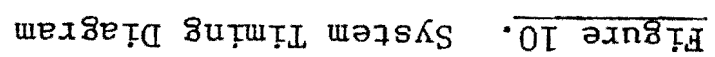

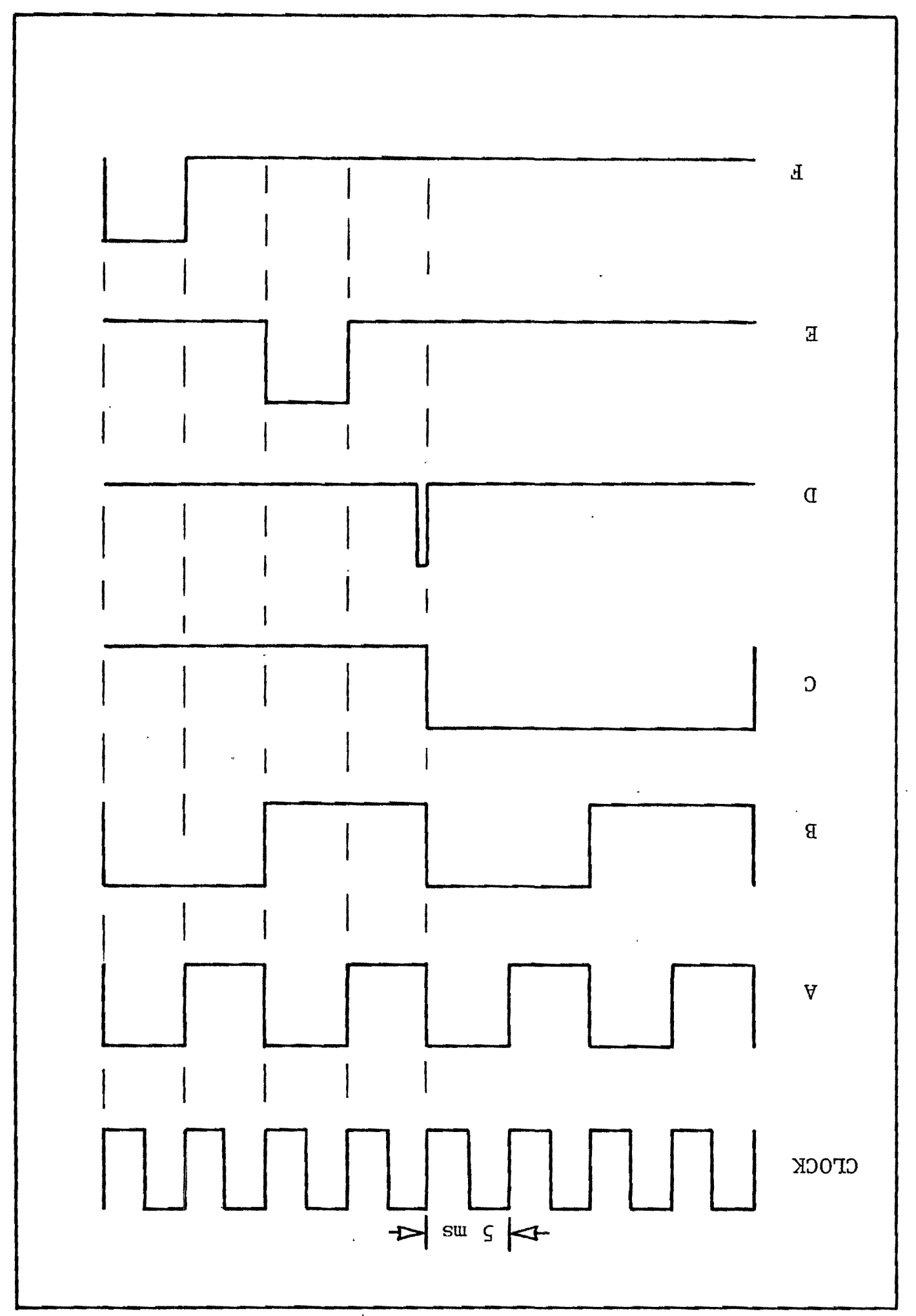




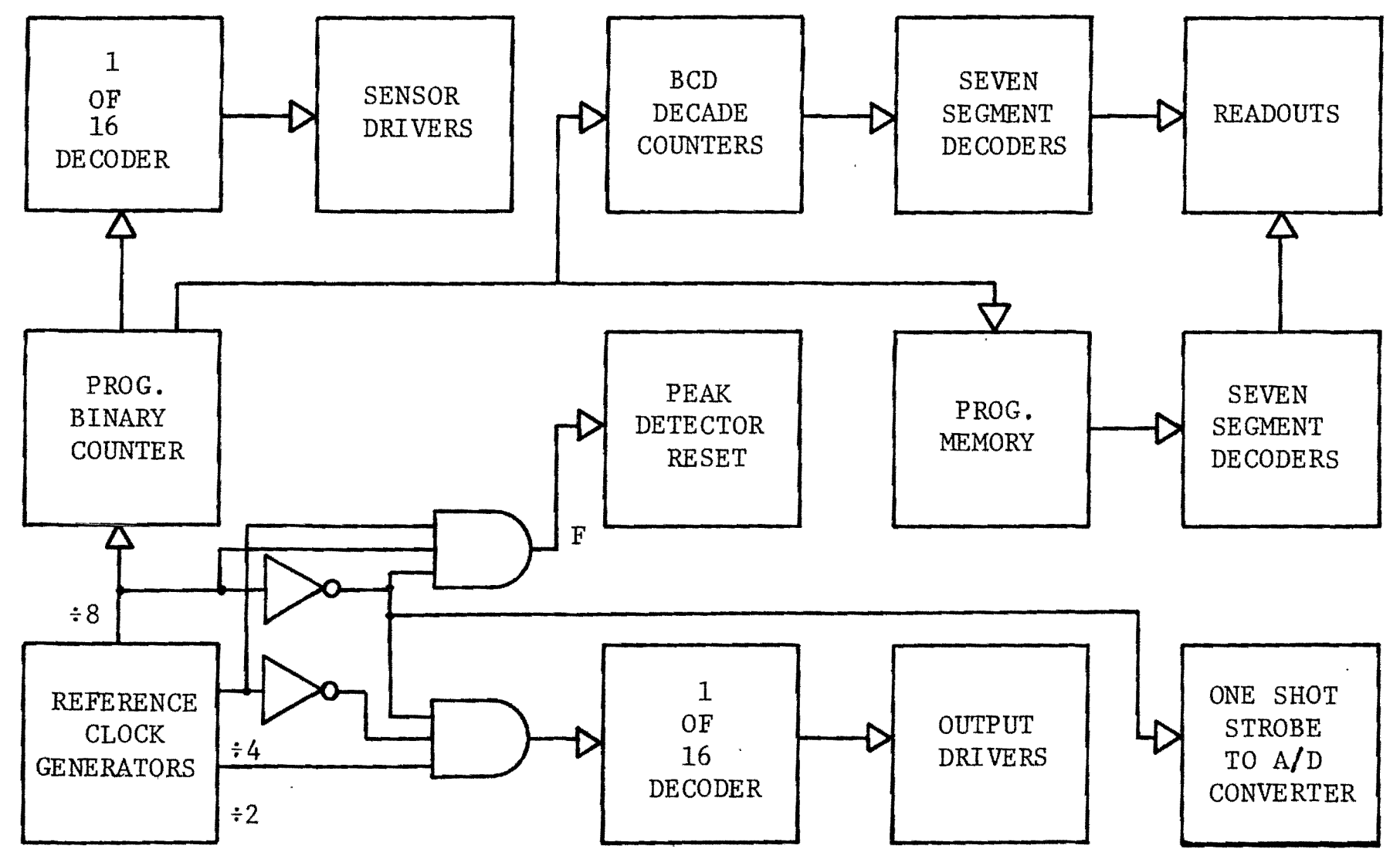

Figure 11. Control Logic Block Diagram 
binary counter (U35). Waveform C provides the input clock pulses for this counter. The output from the counter is a binary coded decimal equivalent to decimal numbers 0 through 15 . The counter can either operate automatically or be programmed externally using four front panel switches. During the standardization process, each rinse tank must be activated individually for periods as long as five minutes. These switches are used to "program in" any one of the sixteen stations. Standardization process is the process by which each sensor is calibrated (programmed) to respond to a predetermined contamination leve1. Calibration is performed using a standard solution of the contaminating agent.

The output of the programmable binary counter is also applied to two "BCD to Seven Segment Decoder/Drivers" whose outputs activate two front panel LED Readouts. These readouts (numbers 0-15), identify the selected station during the manual (calibration) operation. These readouts are inactive during the automatic mode of operation. Waveforms $A, B$, and $C$ are also used to generate wave form $F$.

$$
F=(A \cdot B \cdot \bar{C})
$$

This waveform is used to activate a solid state switch. This switch then shorts out the memory capacitor $\mathrm{C}_{6}$ in the positive peak detector circuit for a period of five milliseconds. The capacitor is then ready to "memorize" a new peak value during the next cycle.

Waveform $\mathrm{D}$ is generated by a retriggerable monostable multivibrator, used as a delay generator. The output pulse has a 1 microsecond duration and is used to strobe the A/D converter into operation. 
It was stated earlier that the output of the $A / D$ converter is applied to the digital comparator. In addition, it performs two other functions as follows:

a) It is applied to three "BCD to Seven Segment Decoder/Drivers". These activate a three digit LED Readout located on the front panel. The A/D converter output has been calibrated so that the resulting readout indicates the resistance of the rinse tank solution. The corresponding conductance $(G)$ can be calculated by dividing this number into one (since $G=1 / R$ ).

b) The output of the $A / D$ converter, along with the corresponding station identification number, is applied to a digital printer. The digital printer is programmed to print the information for a selected rinse tank only. Print command arrives in 1,10 , or 60 second intervals, depending on which interval is pre-selected. This command is initiated from a series of digital dividers (counters) which yield output pulses at 1,10 , or 60 second intervals. These dividers are programmed through switches located on the rear panel of the rinse tank control system.

\section{Power Supply}

The integrated circuits used to design the instrument required \pm 15 volt and +5 volt for operation. A circuit diagram for this power supply is shown in Fig. 12 .

The secondary voltages of transformer $\mathrm{T}_{1}$ are fullwave bridge rectified and filtered. Regulation for the \pm 15 volt supply is provided using two Fairchild UA7815 integrated circuit regulators. +5 volt supply was regulated using a Fairchild UA7805. 


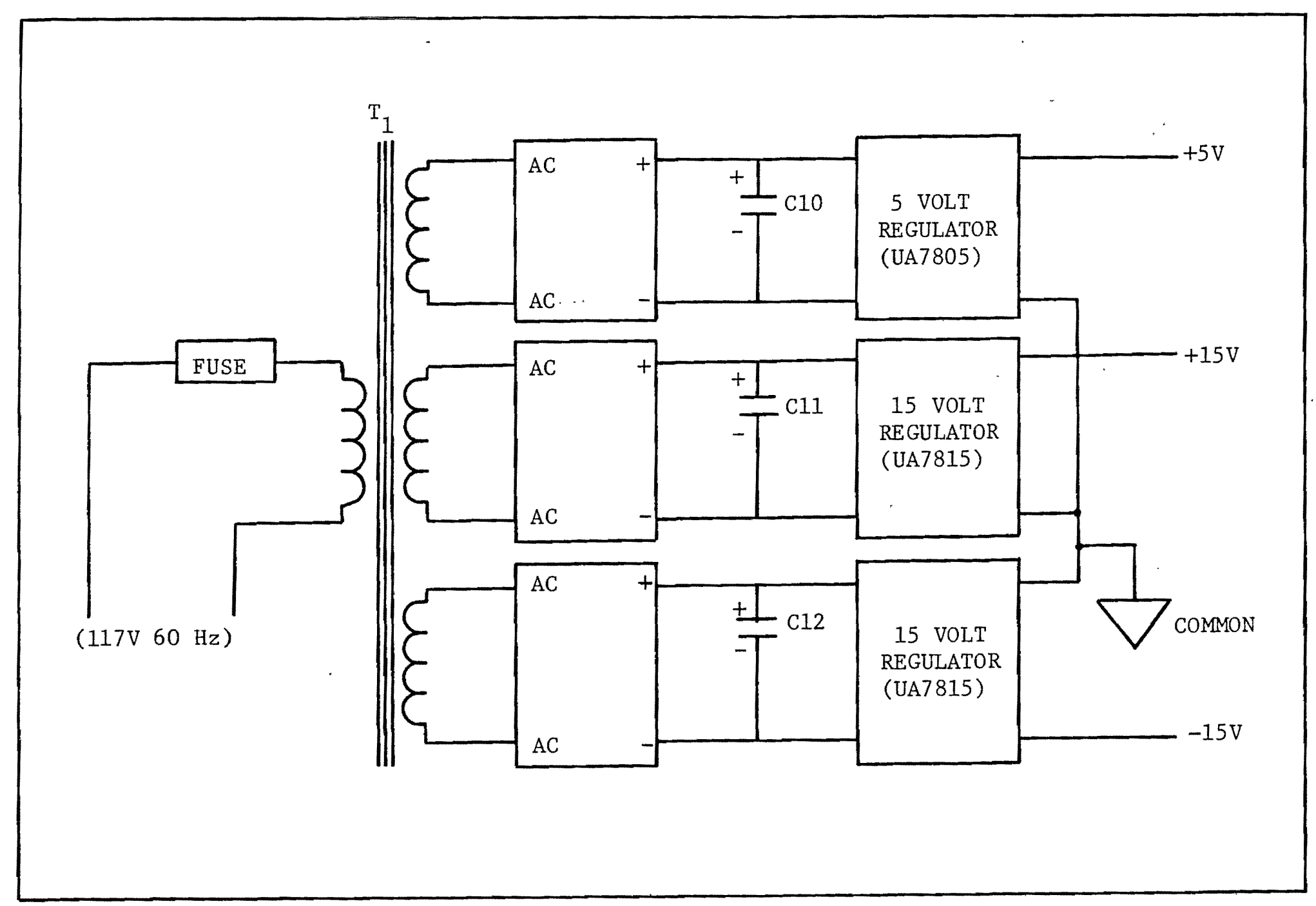

Figure 12. System Power Supply 


\section{Construction}

Monolithic operational amplifiers and TTL (Transister-Transister Logic) family of integrated circuits were utilized as much as possible. With the exception of the digital printer interface, printed circuit boards were used to fabricate the instrument. Digital printer interface was constructed using an "interdyne wire-wrap" board.

In addition to customary precautions, the industrial version incorporated the following safety features:

a) A splash proof, gasketed housing with a corrosion resistant finish which permitted the control unit to be mounted close to the tanks being monitored.

b) A clear lucite window in the control unit front panel which permitted observation of the control settings, yet it kept the controls protected against accidental changes.

c) Green and red indicator lights (instead of LED's which have poor visibility) were used to advise that the unit is functioning and to provide immediate indication of tank status from a distance.

d) Electrical and piping connections were made to conform to government safety regulations.

An automatic temperature compensation network was incorporated in some of the sensors which operated in hot rinse tanks to correct for changes in water temperature. This eliminated the need for the calculation and incorporation of a correction factor based on rinse water temperature since the sensor unit automatically compensated for varying water temperature. 


\section{RESULTS}

RTC-16 was developed for the electrochemical research group at Tektronix, Inc. As stated earlier, this unit was used to investigate the allowable concentration of contaminants in final rinse tanks, and to record cyclic changes in these tanks during peak and slack periods.

A series of experiments were performed during which sixteen rinse tanks were operated under control for a period of two weeks and then allowed to free-flow for the next two weeks. At the end of two months, the results were compared and final conclusions made.

The sole purpose of these experiments was to prove that the rinse tank control system would indeed save on the consumption of water.

A11 tanks were metered and daily readings were taken and recorded. Initially, each station was calibrated by immersing the sensor for that station in a standard solution with varying concentrations depending on rinse type. The concentration level for the standard solutions was prepared using data from an article by Hanson and Zaban (2). Table III shows a number of standard solution concentrations based on the type of rinse used. These standard solution concentration levels were selected as an initial reference since no internal references were available at that time. Because of this fact, the daily reject parts were examined carefully and documented.

If it was found that using a certain standard would result in excessive reject of parts, the standard value would be lowered by about $10 \%$. This would continue until the reject rate fell within an acceptable limit. This procedure resulted in an internal reference table with standard solution values often far from those of the initial reference. 
TABLE III

\begin{tabular}{|c|c|c|}
\hline $\begin{array}{l}\text { Rinse } \\
\text { Type }\end{array}$ & $\begin{array}{l}\text { Concentration } \\
\text { of Standard }\end{array}$ & $\begin{array}{l}\text { Parts Per } \\
\text { Million (PPM) }\end{array}$ \\
\hline $\begin{array}{l}\text { Nickel } \\
\text { Salts }\end{array}$ & $0.005 \mathrm{oz} / \mathrm{Gal}$ & 39 \\
\hline Chromium & $0.0020 z / G a l$ & 16 \\
\hline Cyanide & $0.005 \mathrm{Oz} / \mathrm{Gal}$ & 39 \\
\hline $\begin{array}{l}\text { Alkaline } \\
\text { Cleaner }\end{array}$ & $0.100 \mathrm{Oz} / \mathrm{Gal}$ & 780 \\
\hline Acid & $0.100 \mathrm{oz} / \mathrm{Ga} 1$ & 780 \\
\hline
\end{tabular}

The implementation of a digital printer into the RTC-16 system proved invaluable during these experiments, since it could automatically tabulate the resistance variations in a selected rinse tank for long periods of time. From this, the conductance variation would be calculated (remembering again that $G=1 / R$ ) and used to graph cyclic changes in that rinse tank against the elapsed time. Fig. 13 shows cyclic changes for tank number 371 (chrome rinse after chrome plating) for a three hour period.

At the conclusion of these experiments, the average fresh water consumed by all rinse tanks was found to be 820 gallons per tank during a working week, compared to an average of 3997 gallons per tank under free-flow condition. Based on this, as well as other findings, the following conclusions were made:

a) Installation of an automatic rinse tank control system on most tanks can result in an average savings of $80 \%$ in fresh water consumption. 


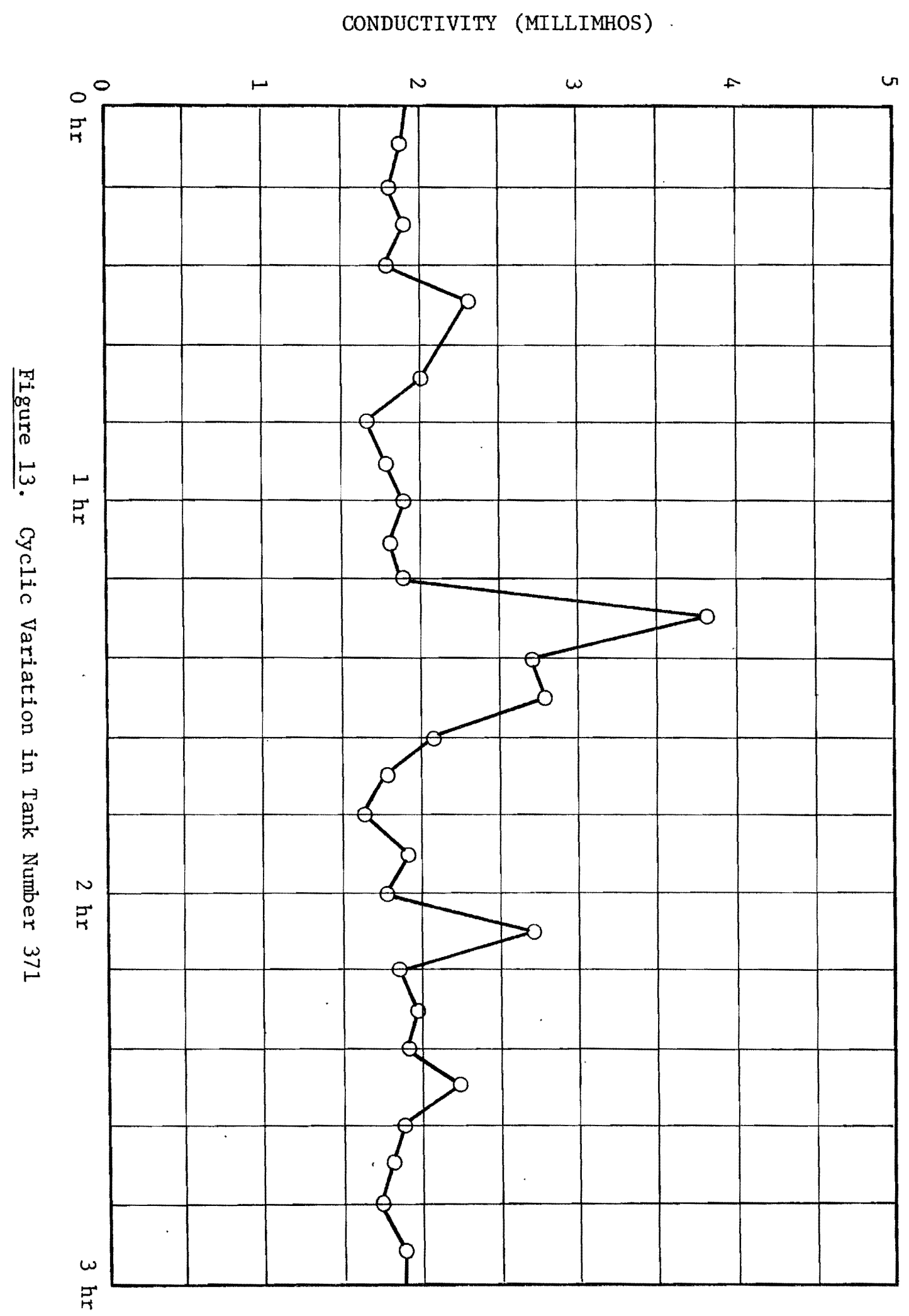


b) In a few critical applications, the contamination level must. be very low ( 5 to $10 \mathrm{ppm}$ ). In these cases, restriction to the flow of water (deionized) is not advisable.

c) Automatic control of rinse tanks will reduce drag-in contamination of plating baths.

d) With a reduction of fluids through the treatment plant, the cost of waste treatment would presently lessen.

e) Less water disposed will decrease the problem of pollution. Up to date, over fifty-five of the industrial version of this instrument (RTC-10) have been installed at different locations through Tektronix. Their use will be extended in the near future to cover company plating operations in Guernsey and Holland as well. 
(1) Walter J. Moore, Physical Chemistry, VIII (Aug. 1961), p. 435.

Prentice-Ha11, Inc., Englewood Cliffs, N.J.

(2) NeI1 H, Hanson and Walter Zabban, "Design and Operation Problems of a Continuous Automatic Plating Waste Treatment PIant", Plating (1959), 46, p. 909 
Daniels, Farrington and Robert A. Alberty 1962. Physical Chemistry, Second Edition. John Wiley \& Sons, Inc., New York

Eimbinder, Jerry 1969. Designing with Linear Integrated Circuits. John Wiley \& Sons, Inc., New York

Emami, A1i and Becky Van Grunsven 1971. Instruction Manual Rinse Tank Contro1 System. Tektronix, Inc., Beaverton, Oregon

Graeme, Jerald G., Gene E. Tobey, and Lawrence P. Huelsman 1971. Operational Amplifiers. McGraw-Hill Book Company, Hightstown, N.J.

Luecke, Gerald, Jack P. Mize and William N. Carr 1973. Semiconductor Memory Design and Application. McGraw-Hill Book Company, Hightstown, N.J.

Millman, Jacob and Christos C. Halkias 1972. Integrated Electronics: Analog and Digital Circuits and Systems. McGraw-Hi11 Book Company, Hightstown, N.J.

Morris, Robert L. and John R. Miller 1971. Designing with TTL Integrated Circuits. McGraw-Hill Book Company, Hightstown, N.J. 


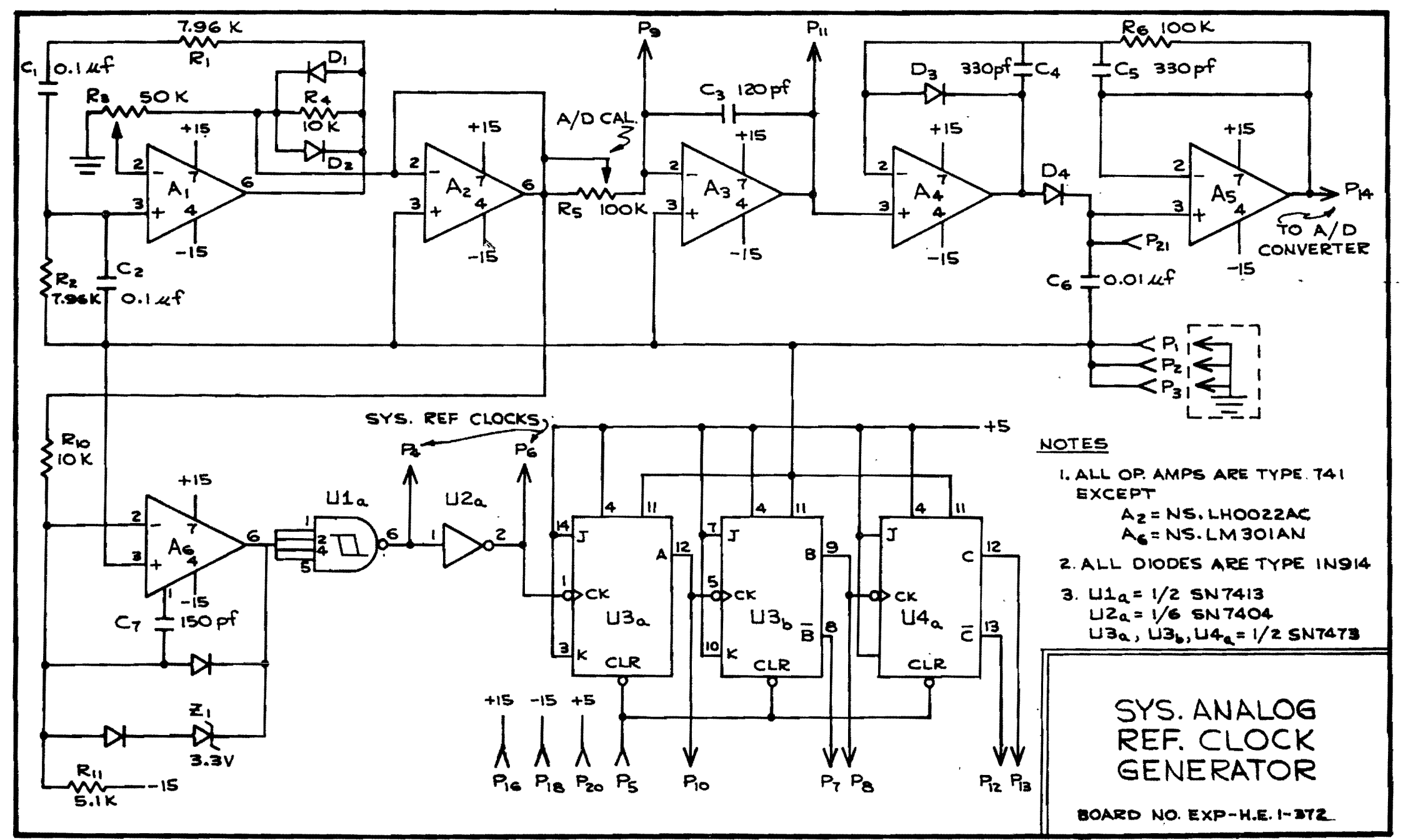




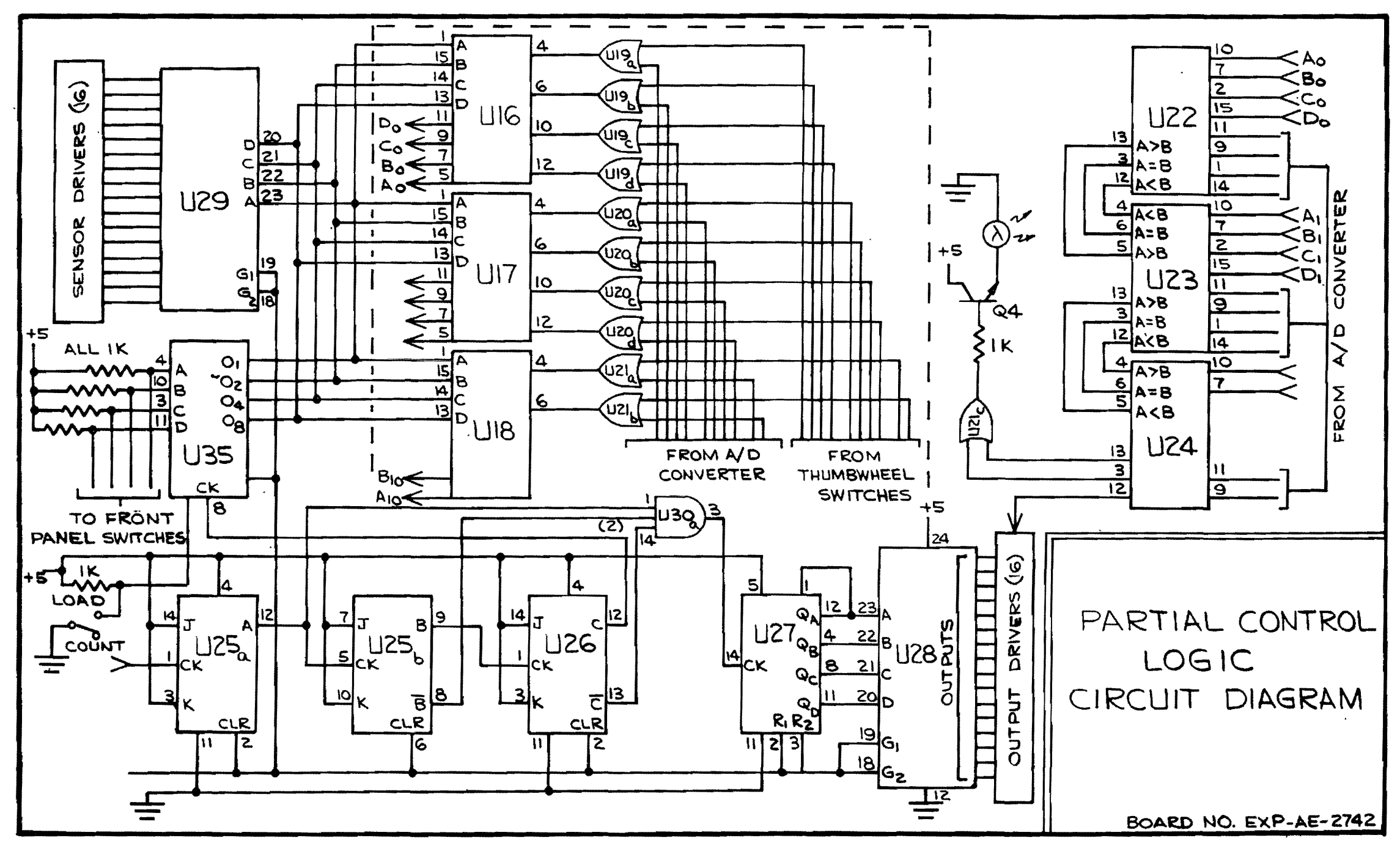




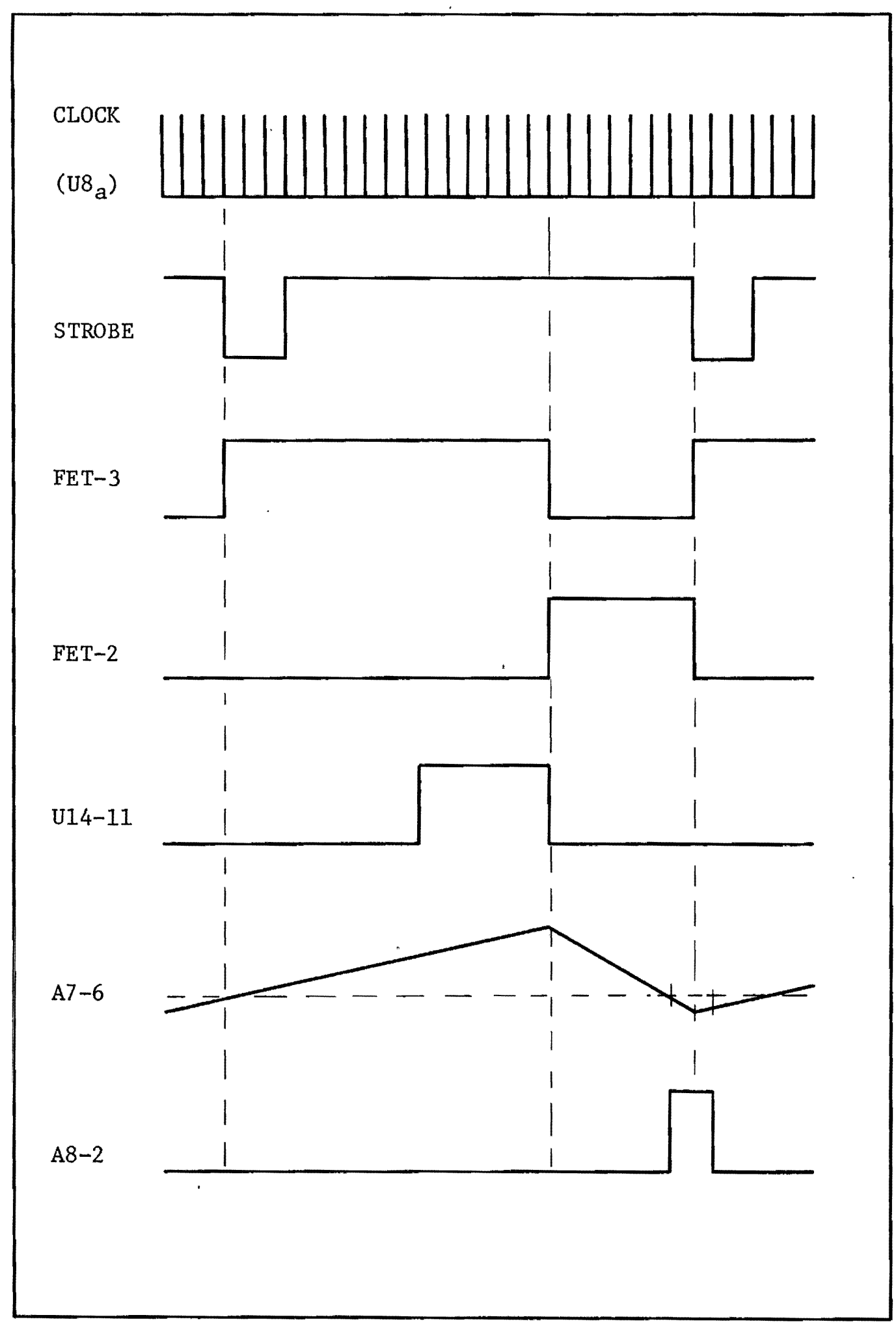

A/D Converter Timing Diagram 


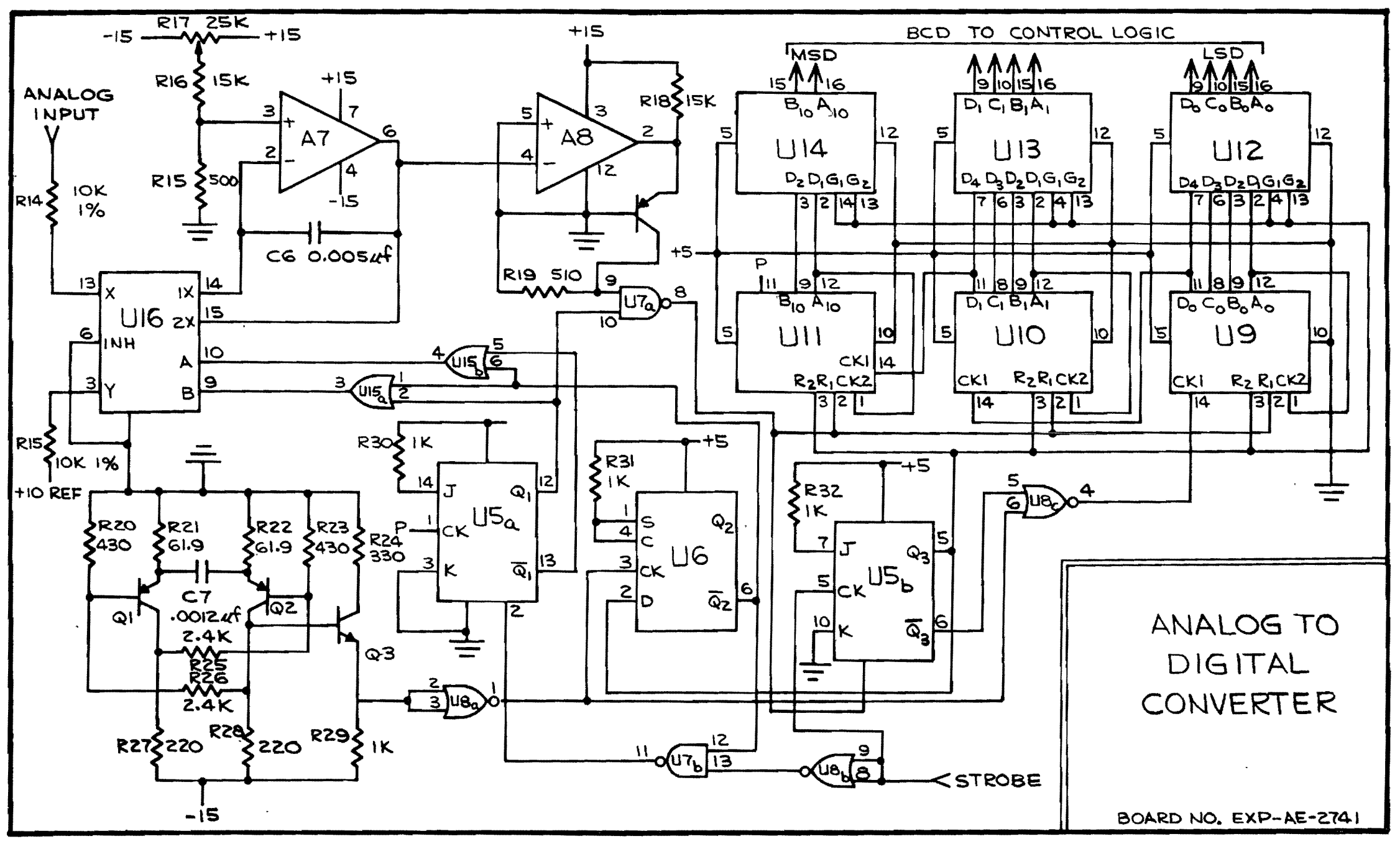

